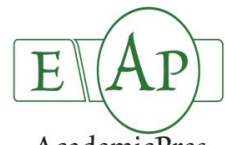

AcademicPres

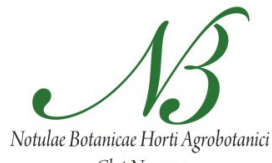

Cluj-Napoca

\title{
Xanthophyll Esters in Fruits and Vegetables
}

\author{
Andrea BUNEA, Carmen SOCACIU, Adela PINTEA* \\ University of Agricultural Sciences and Veterinary Medicine, Department of Chemistry and Biochemistry, 3-5 Mănăştur Street, Cluj-Napoca, Romania; \\ andrea_bunea@yahoo.com; carmen.socaciu@usamvcluj.ro; apintea@usamvcluj.ro (*orrespondingauthor)
}

\begin{abstract}
Carotenoids possessing hydroxyl groups (xanthophylls) are often found as fatty acid esters in many fruits and vegetables. The developments in high resolution chromatographic and spectroscopic techniques have led to a detailed characterization of xanthophyll esters in commonly consumed fruits and vegetables, such as apples, apricots, mandarins, mangoes, papayas, red and chili peppers, potatoes or squash. Some more rich sources have been identified, like wolfberry (goji), sea buckthorn, persimmon, whose popularity is increasing due to the high content of bioactive compounds. Esterification increases the lipophilicity of xanthophylls and contributes to the sequestration of carotenoids, to the formation of specialized structures in the chromoplasts and to an increased photoprotection. The process occurs during ripening in fruits and it is associated with a significant change in colour. Even if the specific enzymes which catalyze the esterification process were not characterized yet in fruits, detailed analytical data regarding the carotenoid composition suggested a selectivity of these enzymes for certain fatty acids and selectivity for the ring in the case of non-symmetric xantophylls. Xanthophyll esters seem to be efficiently hydrolyzed and absorbed in humans leading to a comparable bioavailability to the unesterified compounds. In addition, the xanthophyll esters preserve the antioxidant capacity of the parent compounds while having a better stability in fruits during storage and processing. All these properties are important from the perspective of the use of fruits rich in xanthophyll esters as valuable components of the human diet and as sources of bioactive compounds in the prevention of severe degenerative diseases.
\end{abstract}

Keywords: analysis, antioxidant capacity, biosynthesis and accumulation, bioavailability, stability

\section{Introduction}

Fruits and vegetables are important components of the human diet and they are associated with numerous health benefits due to their high content of micronutrients. Carotenoids are a family of widely distributed lipophilic compounds, comprising more than 750 representatives (Britton et al., 2004). The yellow, orange or red colour of fruits and vegetables is due to the presence of carotenoid pigments. Carotenoids are biosynthesized by plants and some microorganisms but not by animals and human, which rely on their diet to incorporate carotenoids. It is considered that up to $90 \%$ of the carotenoid intake in humans comes from fruits and vegetables (Maiani et al., 2009).

The two classes of carotenoids are carotenes and xanthophylls, which are oxygenated derivatives. Of particular importance among xanthophylls are the hydroxycarotenoids: $\beta$-cryptoxanthin, lutein and zeaxanthin. Some other well known xanthophylls are violaxanthin and neoxanthin in green tissues, capsanthin and capsorubin in pepper, astaxanthin in algae (Haematococcus pluvialis) or pink-flesh fish (Britton and Khachik, 2009; Dufossé, 2009). In fruits and vegetables xanthophylls are present either in a free, unesterified form, or as esters with fatty acids. In some foods like corn, spinach, broccoli or other green leafy vegetables, xanthophylls are present exclusively in unesterified form. In other fruits and vegetables such as pepper, wolfberry, sea buckthorn, apple, squash etc., xanthophylls are mostly found in esterified form (Britton and Khachik, 2009; Pérez-Gálvez and Minguez Mosquera, 2005).

Analysis of carotenoids is usually performed on saponified extracts. Saponification (alkaline hydrolysis) is used to facilitate carotenoid isolation because it is effective in removing contaminating lipids (especially in food-rich samples) and destroying chlorophylls. In the same time, the hydrolysis of carotenoid esters occurs and artefacts can be produced. Due to the fact that xantophylls present in fruits are often esterified, more and more studies are investigating the unsaponified carotenoid extracts which reflect the native composition of the plant food (Giuffrida et al., 2013; Pintea, 2008; Rodriguez-Amaya, 2010).

The best documented function of carotenoids is the provitamin A activity. Carotenoids possessing at least one unsubstituted $\beta$-ring are absorbed and cleaved to form retinol in animals and humans. Food rich in carotenoids are considered to be beneficial in the prevention of severe diseases like cancer, cardiovascular diseases, degenerative diseases, age-related macular degeneration (AMD) and cataract (Krinsky and Johnson, 2005; Landrum et al., 1997; Rao and Rao, 2007). Lutein and zeaxanthin 
311

accumulate in the structures of the human retina, with the highest concentration in the macula were they act as light filter pigments but also as antioxidants (Bernstein et al., 2001). Observational, epidemiological and intervention trials demonstrated that a high concentration of lutein in plasma is correlated with an increase of macular pigment density and a reduced risk of AMD (Chew et al., 2013; Schalch et al., 2009). $\beta$-Cryptoxanthin has provitamin A activity but has also been proved to stimulate bone calcification (Yamaguchi, 2012), to have antiproliferative (Wu et al., 2013) and anti-inflammatory effects (Pattison $e t$ al., 2005).

Taking into account that xanthophylls esters are efficiently absorbed and cleaved into human body and that their availability is comparable with the unesterified form, food rich in esters can be considered a valuable source of biologically active xanthophylls. Furthemore, the xanthophyll esters preserve the well known antioxidant capacity of carotenoids which is associated with most of their biological properties.

\section{Occurrence}

Carotenoid esters occur in flowers, fruits and vegetables. In flower petals, xanthophylls are usually present in esterified form, the best known example being the flowers of Tagetes sp., where more than $90 \%$ of total carotenoids are lutein esters (Gregory et al., 1986; Ohmiya, 2013; PérezGálvez and Minquez-Mosquera, 2005). Lutein, $\beta$ cryptoxanthin, zeaxanthin and violaxanthin are the most frequent xanthophylls found in esterified form in fruits and vegetables and they are located in the specialized structures in chromoplasts (Breithaupt and Bamedi, 2001; Ohmiya, 2013).

The hydroxyl groups of xanthophylls are acylated with saturated fatty acids such as lauric (C12:0), myristic (C14:0), palmitic (C16:0) and stearic (C18:0) acids (Britton et al., 1995a) but unsaturated fatty acids like oleic acid (C18:1), linoleic (C18:2) or linolenic (C18:3) acids were also occasionally reported in fruits, as well as the short chain fatty acids like butyric acid (C4:0).

The most common fruits and vegetables which contain remarkable amounts of xanthophyll esters are: apples (Malus domestica) (Delgado-Pelayo et al., 2014); apricots (Prunus armeniaca L.) (Kurz et al., 2008); mangoes (Mangifera indica L.) (Ornelas-Paz et al., 2007), sea buckthorn berries (Hippophae rhamnoides L.) (Giuffrida et al., 2012; Pop et al., 2014; Weller and Breithaupt, 2003); mandarins (Citrus reticulata) (Giuffrida, 2006); gojis (Lycium barbarum L. and Lycium chinense L.) (Inbaraj et al., 2008; Zhao et al., 2013); papayas (Carica papaya L.) (Schweiggert et al., 2012); oranges (Citrus sinensis L.) (Giuffrida et al., 2010); orange, red and chilli peppers (Capsicum sp.) (Giuffrida et al., 2013; Hornero-Méndez and Minguez-Mosquera, 2000); potatoes (Solanum sp.) (Breithaupt and Bamedi, 2002a; Burmeister et al., 2013; Fernandez-Orozco et al., 2013).

Some other less common fruits which were also reported to contain xanthophyll esters are Chinese lanterns (Physalis alkekengi L.) (Goodwin, 1980; Pintea et al., 2005; Weller and Breithaupt, 2003); persimmon (Diospyros kaki) (Weller and Breithaupt, 2003); yellow raspberries (Rubus idaeus L.) (Carvalho et al., 2013); sarsaparilla berries (Smilax aspera L.) (Delgado-Pelayo and Hornero-Méndez, 2012); corozo, sastra, frutita, maracuja chino, mamey roja (Murillo et al., 2013); cashew apple (Pinto de Abreu et al., 2013).

A very complex screening regarding $\beta$-cryptoxanthin esters was performed by Breithaupt and Bamedi (2001). $\beta$ cryptoxanthin laurate, myristate and palmitate, as well as the free $\beta$-cryptoxanthin, were quantified in several fruits: orange, blood orange, pepper and chili, clementine, papaya, persimmon, tangerine, loquat, kumkuat, nectarine. Similarly, Weller and Breithaupt (2003) determined the zeaxanthin esters (mono and diesters with laurate, myristate, palmitate and stearate) in red and orange pepper, sea buckthorn, wolfberries, Chinese lanterns and persimmon. In both studies, LC/MS/APCI was used for separation and identification, as well as standard esters obtained by semisynthesis.

Carotenoid composition and concentration in fruits is influenced by genetic and environmental factors, such as: cultivar, maturity, climate, geographic area, processing and storage (Rodriguez-Amaya, 2010). Absolute quantitative data for the carotenoid esters content are difficult to be set. However, pepper and chilli (orange, red), wolfberry, papaya, tangerines, persimmon and sea bukhthorn seem to be among the richest sources (Breithaupt and Bamedi, 2001; Weller and Breithaupt, 2003). Detailed composition of xanthophyll esters in selected fruits, including the fatty acids esterifying the hydroxyl groups are presented in Tab. 1 .

Tab. 1. Distribution, extraction and analytical procedures for separation and identification of xanthophyll esters in selected fruits

\begin{tabular}{|c|c|c|c|c|c|c|}
\hline Fruit & Analyte & $\begin{array}{c}\text { Extraction } \\
\text { protocol }\end{array}$ & $\begin{array}{c}\text { Column } \\
\text { (stationary } \\
\text { phase) }\end{array}$ & Mobile phase & $\begin{array}{l}\text { Detection } \\
\text { system }\end{array}$ & References \\
\hline $\begin{array}{l}\text { Capsicum } \\
\text { varieties }\end{array}$ & $\begin{array}{c}\text { Cis-capsanthin-esters: C12:0; C14:0 } \\
\text { Antheraxanthin esters: C12:0; C14:0) } \\
\text { Capsanthin-5,6-epoxy esters: C14:0 } \\
\text { Lutein esters: C14:0 } \\
\text { Capsanthin esters: C12:0; C14:0; C16:0; C14:0- } \\
\text { C14:0; C12:0-C16:0; C14:0-C16:0; C16:0-C16:0 } \\
\text { Zeaxanthin esters: C12:0; C14:0; C16:0; C12:0- } \\
\text { C12:0; C12:0-C14:0; C14:0-C14:0; C14:0-C16:0; } \\
\text { C16:0-C16:0 } \\
\text { 3-cryptoxanthin esters: C12:0; C14:0; C16:0 } \\
\text { Cyptocapsin esters: C14:0; C16:0 } \\
\text { Capsorubin diesters: C14:0-C14:0; C14:0-C16:0 }\end{array}$ & Acetone & $\begin{array}{c}\text { YMC C } 30 \\
(250 \times 4.6 \mathrm{~mm} \\
5 \mu \mathrm{m})\end{array}$ & $\begin{array}{c}\text { (A): } \\
\text { MeOH:TBME: } \mathrm{H}_{2} \mathrm{O} \\
\text { 82:16:2 (v/v/v) } \\
\text { (B): } \\
\text { MeOH:TBME: } \mathrm{H}_{2} \mathrm{O} \\
\text { 10:88:2 (v/v/v) }\end{array}$ & $\begin{array}{l}\text { HPLC- } \\
\text { DAD- } \\
\text { APCI-MS }\end{array}$ & $\begin{array}{l}\text { Giuffrida } \\
\text { et al., } 2013\end{array}$ \\
\hline
\end{tabular}




\begin{tabular}{|c|c|c|c|c|c|c|}
\hline $\begin{array}{c}\text { Spice } \\
\text { paprika } \\
\text { (Capsicum } \\
\text { annum L.) }\end{array}$ & $\begin{array}{c}\text { Capsorubin methyl ester } \\
\text { Cucurbitaxanthin methyl ester } \\
\text { Capsanthin epoxide methyl ester } \\
\text { Capsanthin methyl ester-1 } \\
\text { Cryptoxanthin methyl ester } \\
\text { Capsanthin ME-2ME } \\
\text { Antheraxanthin ME } \\
\text { Zeaxanthin ME and DE } \\
\text { Capsanthin DE }\end{array}$ & $\begin{array}{l}\text { Dichlorethane } \\
\text { Acetone/ } \\
\text { Methanol } \\
(2: 1: 1, \mathrm{v} / \mathrm{v} / \mathrm{v})\end{array}$ & $\begin{array}{l}\text { Purospher C-18 } \\
(250 \times 4.6 \mathrm{~mm} \\
3 \mu \mathrm{m})\end{array}$ & $\begin{array}{c}\text { A: } \mathrm{H}_{2} \mathrm{O} \\
\text { B: } \mathrm{MeOH} \\
\text { C: } \\
\text { Methanol/Isopropanol } \\
/ \\
\text { Acetonitrile } \\
\text { 10:55:35 }(\mathrm{v} / \mathrm{v} / \mathrm{v})\end{array}$ & LC-MS & $\begin{array}{l}\text { Daood, et al. } \\
\quad 2014\end{array}$ \\
\hline Mango & $\begin{array}{l}\text { 9-cis-violaxanthin esters: C4:0; C4:0- C4:0 } \\
\text { all-trans-violaxanthin: C4:0-C4:0; C4:0-C6:0 }\end{array}$ & Methanol & $\begin{array}{l}\text { YMC C } 30 \\
(150 \times 4.6 \mathrm{~mm} \\
3 \mu \mathrm{m}) \\
15^{\circ} \mathrm{C}\end{array}$ & $\begin{array}{l}\text { A: Water } \\
\text { B: MeOH } \\
\text { C: MTBE }\end{array}$ & $\begin{array}{l}\text { LC-APCI+- } \\
\text { MS }\end{array}$ & $\begin{array}{l}\text { Ornelas-Paz } \\
\text { et al., } 2007\end{array}$ \\
\hline \multirow{2}{*}{$\begin{array}{l}\text { Sea } \\
\text { buckthorn } \\
\text { (Hippophae } \\
\text { rhamnoides } \\
\text { L.) }\end{array}$} & $\begin{array}{c}\text { Lutein esters: C16:3; } \mathrm{C} 16: 2 ; \mathrm{C} 18: 2 ; 18: 1 ; \mathrm{C} 16: 0-\mathrm{C} 16: 0 \\
\text { Zeaxanthin esters: C14:0; C16:0; } 14: 0-14: 0 ; \mathrm{C} 16: 0-16: 1 ; \\
\text { C14:0-16:0; } \mathrm{C} 16: 0-16: 0 \\
\text { B-cryptoxanthin esters: } \mathrm{C} 14: 0 ; \mathrm{C} 16: 0\end{array}$ & $\begin{array}{l}\text { Methanol/ } \\
\text { Ethyl Acetate/ } \\
\text { Petroleum } \\
\text { Ether, } \\
(1 / 1 / 1 ; \mathrm{v} / \mathrm{v} / \mathrm{v})\end{array}$ & $\begin{array}{l}\text { YMC C } 30 \\
(250 \times 4.6 \mathrm{~mm}-5 \\
\mu \mathrm{m})\end{array}$ & $\begin{array}{c}\text { A: } \\
\text { Methanol/MTBE } / \mathrm{H}_{2} \\
\mathrm{O} \\
(83: 15: 2, \mathrm{v} / \mathrm{v} / \mathrm{v}) \\
\text { B: } \\
\text { Methanol/MTBE/H } \\
\mathrm{O} \\
(8: 90: 2, \mathrm{v} / \mathrm{v} / \mathrm{v})\end{array}$ & $\begin{array}{l}\text { HPLC- } \\
\text { DAD- } \\
\text { APCI-MS }\end{array}$ & $\begin{array}{l}\text { Giuffrida } e t \\
a l, 2012\end{array}$ \\
\hline & $\begin{array}{c}\text { B-cryptoxanthin esters: C16:0 } \\
\text { Zeaxanthin esters: C14:0; C16:0; C14:0-C16:0; C16:0:C16:0 } \\
\text { Lutein esters: C16:0; C14:0-14:0; C14:0-16:0; C16:0-C18:0 }\end{array}$ & $\begin{array}{l}\text { Methanol/ } \\
\text { Ethyl Acetate/ } \\
\text { Petroleum } \\
\text { Ether, } \\
(1 / 1 / 1 ; \mathrm{v} / \mathrm{v} / \mathrm{v})\end{array}$ & $\begin{array}{c}\text { LiChrosorb RP } \\
18(250 \times 4.6 \\
\mathrm{mm}, 5 \mu \mathrm{m}) \\
\text { RP } 18 \text { UPLC } \\
\text { BEH Shield } \\
(2.1 \times 150 \mathrm{~mm}, \\
1,7 \mu \mathrm{m})\end{array}$ & $\begin{array}{c}\text { A: AcCN: } \mathrm{H}_{2} \mathrm{O} 9: 1 \\
\text { B: AcEt } \\
\\
\text { A: Ac Ethyl } \\
\text { B: Acetonitrile } \\
\text { C: Acetonitrile: } \mathrm{H}_{2} \mathrm{O} \\
\quad(1: 1, \mathrm{v} / \mathrm{v})\end{array}$ & $\begin{array}{l}\text { RP-PDA- } \\
\text { HPLC } \\
\text { UHPLC- } \\
\text { PAD-ESI- } \\
\text { MS }\end{array}$ & $\begin{array}{l}\text { Pop et al., } \\
\quad 2014\end{array}$ \\
\hline $\begin{array}{l}\text { Mandarin } \\
\text { essential oil }\end{array}$ & $\beta$-cryptoxanthin esters: $\mathrm{C} 12: 0 ; \mathrm{C} 14: 0 ; \mathrm{C} 16: 0$ & $\begin{array}{l}\text { Oil:TBME } \\
\quad(1: 1)\end{array}$ & $\begin{array}{l}\text { YMC C } 30 \\
(250 \times 4.6 \mathrm{~mm} \\
5 \mu \mathrm{m})\end{array}$ & $\begin{array}{l}\text { A: } \mathrm{MeOH} \\
\text { B: MTBE }\end{array}$ & $\begin{array}{l}\text { HPLC- } \\
\text { PDA-APCI- } \\
\text { MS }\end{array}$ & $\begin{array}{c}\text { Giuffrida } e t \\
\text { al., } 2006\end{array}$ \\
\hline $\begin{array}{l}\text { Sarsaparilla } \\
\text { berries } \\
\text { (Smilax } \\
\text { aspera L.) }\end{array}$ & $\begin{array}{l}\text { Zeaxanthin monoester: C14:0 } \\
\text { B-cryptoxanthin esters: C10:0; C12:0; C14:0; C16:0; C18:0 }\end{array}$ & acetone & $\begin{array}{c}\text { RP C } 18 \\
\text { Mediterranea } \\
\text { SEA } 18 \\
(200 \times 4.6 \mathrm{~mm}, 3 \\
\mu \mathrm{m}) ; 25^{\circ} \mathrm{C}\end{array}$ & $\begin{array}{l}\text { A: Acetone } \\
\text { B: } \mathrm{H}_{2} \mathrm{O}\end{array}$ & $\begin{array}{l}\text { LC-MS } \\
(\text { APCI+) }\end{array}$ & $\begin{array}{l}\text { Delgado- } \\
\text { Pelayo and } \\
\text { Hornero- } \\
\text { Méndez, } \\
2012\end{array}$ \\
\hline Mandarin & $\begin{array}{l}\text { B-cryptoxanthin esters: C10:0; C12:0; C14:0; C16:0 } \\
\text { Mutatoxanthin isomer esters: C10:0; C12:0 } \\
\text { Lutein esters: C14:0; C16:0; C18:0; C18:1 } \\
\text { Mutatoxanthin esters: C16:0; C18:0 } \\
\text { Luteoxanthin esters: C10:0; C12:0; C14:0 }\end{array}$ & $\begin{array}{c}\text { Essential oil } \\
\text { injected directly }\end{array}$ & $\begin{array}{c}\text { Discovery Cyano } \\
(250 \times 1 \mathrm{~mm} ; \\
5 \mu \mathrm{m}) \\
\text { Chromolith } \\
\text { Performance RP- } \\
18 \\
(100 \times 4.6 \mathrm{~mm})\end{array}$ & $\begin{array}{l}\text { A: } \mathrm{n} \text {-hexane } \\
\text { B: } \mathrm{n} \text {-hexane/ } \\
\text { butylacetat } / \text { acetone } \\
\text { (80:15:5) } \mathrm{v} / \mathrm{v} / \mathrm{v} \\
\text { A: } 2 \text {-propanol } \\
\text { B: } 20 \% \text { water in } \\
\text { acetonitrile }(\mathrm{v} / \mathrm{v})\end{array}$ & $\begin{array}{l}\text { LC x LC, } \\
\text { DAD/ } \\
\text { APCI }\end{array}$ & $\begin{array}{l}\text { Dugo et al., } \\
2008\end{array}$ \\
\hline $\begin{array}{l}\text { Orange } \\
\text { juices }\end{array}$ & $\begin{array}{c}\text { cis-violaxanthin esters: C10:0; C12:0; C14:0; C16:0; C12:0- } \\
\text { C12:0; C12:0-C14:0; C14:0- C14:0; } \\
\text { C14:0-C16:0; C16:0- C16:0 } \\
\text { Luteoxanthin esters: C12:0; C14:0; C16:0 } \\
\text { Auroxanthin: C16:0 } \\
\text { Antheraxanthin: C16:0 } \\
\text { Mutatoxanthin (C16:0) } \\
\text { B-cryptoxanthin (C12:0; C14:0; C16:0) }\end{array}$ & $\begin{array}{l}\text { Methanol/ } \\
\text { Ethyl Acetate/ } \\
\text { Petroleum } \\
\text { Ether, } \\
(1 / 1 / 1 ; \mathrm{v} / \mathrm{v} / \mathrm{v})\end{array}$ & $\begin{array}{l}\text { YMC C } 30 \\
(250 \times 4.6 \mathrm{~mm} \\
5 \mu \mathrm{m}) \\
23^{\circ} \mathrm{C}\end{array}$ & $\begin{array}{c}\text { A: } \\
\text { Methanol/MTBE/Wa } \\
\text { ter } \\
(90: 7: 3 ; \mathrm{v} / \mathrm{v} / \mathrm{v}) \\
\text { B: Methanol/MTBE } \\
(10: 90 ; \mathrm{v} / \mathrm{v})\end{array}$ & $\begin{array}{l}\text { LC-MS- } \\
\text { APCI }\end{array}$ & $\begin{array}{l}\text { Giuffrida } e t \\
\text { al., } 2010\end{array}$ \\
\hline $\begin{array}{l}\text { Apricots } \\
\text { (Prunus } \\
\text { armeniaca } \\
\text { L.) }\end{array}$ & $\begin{array}{r}\text { B-criptoxanthin esters (C12:0; C18:1; C16:0; C18:1-C18:1; } \\
\text { C16:0-C18:1) Lutein esters (C18:1- C18:1; C16:0- C18:1; } \\
\text { C12:0- C12:0; C12:0- C14:0; C14:0-C14:0; C14:0-C16:0; } \\
\text { C16:0- C16:0) } \\
\text { Antheraxanthin esters (C12:0; C14:0; C16:0) }\end{array}$ & $\begin{array}{c}\text { Acetone/ } \\
\text { Hexane } \\
(1: 1 ; \mathrm{v} / \mathrm{v})\end{array}$ & $\begin{array}{l}\mathrm{C} 30 \mathrm{YMC} \\
150 \times 3 \mathrm{~mm} \\
3 \mu \mathrm{m} \\
25^{\circ} \mathrm{C}\end{array}$ & $\begin{array}{c}\text { A:Methanol/MTBE/ } \\
\mathrm{H}_{2} \mathrm{O} \\
(81: 15: 4 \mathrm{v} / \mathrm{v} / \mathrm{v}) \mathrm{B}: \\
\text { Methanol/MTBE/H } \\
\mathrm{O}(4: 92: 4 \mathrm{v} / \mathrm{v} / \mathrm{v})\end{array}$ & LC-MS & $\begin{array}{l}\text { Kurz et al., } \\
\quad 2008\end{array}$ \\
\hline $\begin{array}{c}\text { Yellow } \\
\text { raspberries } \\
(\text { Rubus } \\
\text { idaeus } \mathrm{L} .)\end{array}$ & Lutein mono and diesters: $\mathrm{C} 8: 0 ; \mathrm{C} 10: 0 ; \mathrm{C} 12: 0: \mathrm{C} 14: 0 ; \mathrm{C} 16: 0$ & $\begin{array}{c}\text { Methanol/Tris- } \\
\text { HCl buffer/ } \\
\text { Chloroform } \\
(1: 1: 4, \mathrm{v} / \mathrm{v} / \mathrm{v})\end{array}$ & $\begin{array}{l}\text { C30 YMC } \\
(250 \times 4.6 \mathrm{~mm} \\
5 \mu \mathrm{m})\end{array}$ & $\begin{array}{c}\text { A: } \mathrm{MeOH} \\
\text { B: } \mathrm{H}_{2} \mathrm{O} / \mathrm{MeOH} \\
(20 / 80 \mathrm{v} / \mathrm{v}) \\
+0,2 \% \text { ammonium } \\
\text { acetate } \\
\text { C: TMBE }\end{array}$ & $\begin{array}{l}\text { LC-APCI- } \\
\text { MS }\end{array}$ & $\begin{array}{l}\text { Carvalho } e t \\
\text { al., } 2013\end{array}$ \\
\hline $\begin{array}{c}\text { Apple } \\
\text { (flesh and } \\
\text { peel) }\end{array}$ & $\begin{array}{r}\text { all-trans-Neoxanthin esters: C10:0-C10:0, C10:0-C12:0; } \\
\text { C12:0-C12:0; C12:0-C14:0; C14:0; C14:0-C14:0; C16:0; } \\
\text { C16:0-C16:0; C16:0-C18:0 } \\
\text { all-trans-Violaxanthin esters: C10:0-C10:0; C10:0-C12:0; } \\
\text { C12:0-C12:0; C12:0-C14:0; C14:0-C14:0; C14:0-C16:0; } \\
\text { C16:0-C16:0; C16:0-C18:0 } \\
\text { 9-cis-Violaxanthin esters: C10:0-C10:0; C10:0-C12:0; C12:0- } \\
\text { C12:0; C12:0-C14:0; C14:0-C14:0; C14:0-C16:0; C16:0- } \\
\text { C16:0; C16:0-C18:0 }\end{array}$ & $\begin{array}{l}\mathrm{N}, \mathrm{N} \text {-dimethyl- } \\
\text { formamide }\end{array}$ & $\begin{array}{c}\text { RP-C18 } \\
\text { Mediterranea } \\
\text { SEA } 18 \\
(200 \times 4.6 \mathrm{~mm}, \\
3 \mu \mathrm{m}) \\
25^{\circ} \mathrm{C}\end{array}$ & $\begin{array}{l}\text { A: Acetone } \\
\text { B: Deionised water }\end{array}$ & $\begin{array}{l}\text { LC-MS } \\
(\text { APCI+) }\end{array}$ & $\begin{array}{l}\text { Delgado- } \\
\text { Pelayo } \text { et al., } \\
2014\end{array}$ \\
\hline $\begin{array}{c}\text { Goji } \\
\text { (Lycium } \\
\text { barbarum) }\end{array}$ & $\begin{array}{l}\text { Zeaxanthin esters: } \mathrm{C} 16: 0 ; \mathrm{C} 16: 0-\mathrm{C} 16: 0 \\
\quad \beta \text {-cryptoxanthin esters: } \mathrm{C} 16: 0\end{array}$ & $\begin{array}{c}\text { Hexane/ } \\
\text { Ethanol/ } \\
\text { Acetone } \\
\text { Toluene } \\
(10: 6: 7: 7, \\
\mathrm{v} / \mathrm{v} / \mathrm{v} / \mathrm{v})\end{array}$ & $\begin{array}{l}\mathrm{C} 30 \\
25^{\circ} \mathrm{c}\end{array}$ & $\begin{array}{c}\text { A: Dichloromethane } \\
\text { B: } \\
\text { Methanol/Acetonitrile } \\
/ \\
\text { Water } \\
(84: 14: 5, \mathrm{v} / \mathrm{v} / \mathrm{v})\end{array}$ & $\begin{array}{l}\text { HPLC- } \\
\text { DAD- } \\
\text { APCI-MS }\end{array}$ & $\begin{array}{l}\text { Inbaraj et al., } \\
2008\end{array}$ \\
\hline
\end{tabular}


313

\begin{tabular}{|c|c|c|c|c|c|c|}
\hline $\begin{array}{l}\text { Corozo } \\
(A . \\
\text { aculeate })\end{array}$ & $\begin{array}{l}\text { Zeaxanthin esters (C10:0; C12:0; C16:0; C10:0- C10:0; } \\
\text { C10:0- C12:0; C12:0- C12:0; C12:0-C14:0; C10:0-C16:0; } \\
\text { C14:0-C14:0; C12:0-C16:0; C14:0-C16:0; C16:0-C16:0) } \\
\text { ß-criptoxanthin esters (C8:0; C10:0; C12:0; C14:0; C16:0) }\end{array}$ & Acetone & $\begin{array}{l}\text { YMC C } 30 \\
(250 \times 4.6 \\
\mathrm{mm} \\
5 \mu \mathrm{m})\end{array}$ & $\begin{array}{c}\text { A: Methanol/MTBE } / \mathrm{H}_{2} \mathrm{O} \\
\quad(81: 17: 2, \mathrm{v} / \mathrm{v} / \mathrm{v}) \\
\text { B: Methanol/MTBE/ } \mathrm{H}_{2} \mathrm{O} \\
\quad(10: 88: 2, \mathrm{v} / \mathrm{v} / \mathrm{v})\end{array}$ & $\begin{array}{l}\text { HPLC- } \\
\text { DAD- } \\
\text { APCI-MS }\end{array}$ & $\begin{array}{c}\text { Murillo et } \\
\text { al., } 2013\end{array}$ \\
\hline
\end{tabular}

\begin{tabular}{|c|c|c|c|c|c|c|}
\hline $\begin{array}{l}\text { Sastra } \\
\quad(G . \\
\text { intermedia })\end{array}$ & $\begin{array}{l}\text { B-criptoxanthin esters (C12:0; C14:0; C16:0) } \\
\text { Lutein esters (C12:0- C12:0; C12:0-C14:0; } 12: 0-\mathrm{C} 16: 0) \\
\text { Zeaxanthin esters (C14:0- C14:0; } 14: 0-\mathrm{C} 16: 0 ; \mathrm{C} 16: 0-\mathrm{C} 16: 0)\end{array}$ & Acetone & $\begin{array}{l}\text { YMC C } 30 \\
(250 \times 4.6 \\
\mathrm{mm} \\
5 \mu \mathrm{m})\end{array}$ & $\begin{array}{c}\text { A: Methanol/MTBE } / \mathrm{H}_{2} \mathrm{O} \\
\quad(81: 17: 2, \mathrm{v} / \mathrm{v} / \mathrm{v}) \\
\text { B: Methanol/MTBE/ } \mathrm{H}_{2} \mathrm{O} \\
\quad(10: 88: 2, \mathrm{v} / \mathrm{v} / \mathrm{v})\end{array}$ & $\begin{array}{l}\text { HPLC- } \\
\text { DAD- } \\
\text { APCI-MS }\end{array}$ & $\begin{array}{l}\text { Murillo } e t \\
\text { al., } 2013\end{array}$ \\
\hline $\begin{array}{c}\text { Sapote } \\
\text { (Q. cordata) }\end{array}$ & $\begin{array}{c}\text { n.i. (xanthophyll esters) } \\
\text { Zeaxanthin esters (C12:0- C12:0; C12:0- C14:0; C14:0- } \\
\text { C18:1; C14:0- C14:0; C12:0- C16:0; C16:0-C18:1; C14:0- } \\
\text { C16:0; C16:0- C16:0; C16:0- C18:0; C18:0- C18:0) }\end{array}$ & Acetone & $\begin{array}{l}\text { YMC C } 30 \\
(250 \times 4.6 \\
\mathrm{mm} \\
5 \mu \mathrm{m})\end{array}$ & $\begin{array}{c}\text { A: Methanol/MTBE } / \mathrm{H}_{2} \mathrm{O} \\
\quad(81: 17: 2, \mathrm{v} / \mathrm{v} / \mathrm{v}) \\
\text { B: Methanol/MTBE/ } \mathrm{H}_{2} \mathrm{O} \\
(10: 88: 2, \mathrm{v} / \mathrm{v} / \mathrm{v})\end{array}$ & $\begin{array}{l}\text { HPLC- } \\
\text { DAD- } \\
\text { APCI-MS }\end{array}$ & $\begin{array}{c}\text { Murillo et } \\
\text { al., } 2013\end{array}$ \\
\hline $\begin{array}{l}\text { Frutita } \\
\text { A. } \\
\text { psilospermus }\end{array}$ & $\begin{array}{l}\text { n.i. (cis-Apo-carotenoid- ester) }(\mathrm{C} 8: 0 ; \mathrm{C} 12: 0 ; \mathrm{C} 14: 0 ; \mathrm{C} 16: 0) \\
\quad \beta \text {-citraurin (C6:0; C8:0; C10:0; C12:0; C14:0; C16:0) }\end{array}$ & Acetone & $\begin{array}{l}\text { YMC C } 30 \\
(250 \times 4.6 \\
\mathrm{mm} \\
5 \mu \mathrm{m})\end{array}$ & $\begin{array}{c}\text { A: Methanol/MTBE } / \mathrm{H}_{2} \mathrm{O} \\
\quad(81: 17: 2, \mathrm{v} / \mathrm{v} / \mathrm{v}) \\
\text { B: Methanol/MTBE/ } / \mathrm{H}_{2} \mathrm{O} \\
\quad(10: 88: 2, \mathrm{v} / \mathrm{v} / \mathrm{v})\end{array}$ & $\begin{array}{l}\text { HPLC- } \\
\text { DAD- } \\
\text { APCI-MS }\end{array}$ & $\begin{array}{c}\text { Murillo et } \\
\text { al., } 2013\end{array}$ \\
\hline $\begin{array}{l}\text { Maracuja } \\
\text { chino }(C \\
\text { macrantis })\end{array}$ & $\begin{array}{c}\text { n.i. (xanthophyll esters) } \\
\text { Cryptocapsin (C12:0) } \\
\beta \text { - cryptoxanthin esters (C12:0; C14:0; C16:0) }\end{array}$ & Acetone & $\begin{array}{c}\text { YMC C } 30 \\
(250 \times 4.6 \\
\mathrm{mm} \\
5 \mu \mathrm{m})\end{array}$ & $\begin{array}{c}\text { A: Methanol/MTBE } / \mathrm{H}_{2} \mathrm{O} \\
(81: 17: 2, \mathrm{v} / \mathrm{v} / \mathrm{v}) \\
\text { B: Methanol/MTBE/ } \mathrm{H}_{2} \mathrm{O} \\
(10: 88: 2, \mathrm{v} / \mathrm{v} / \mathrm{v})\end{array}$ & $\begin{array}{l}\text { HPLC- } \\
\text { DAD- } \\
\text { APCI-MS }\end{array}$ & $\begin{array}{c}\text { Murillo et } \\
\text { al., } 2013\end{array}$ \\
\hline $\begin{array}{l}\text { Mamey } \\
\text { rojo }(P \text {. } \\
\text { sapata })\end{array}$ & $\begin{array}{c}\text { Cryptocapsin-5,6-epoxide ester: C12:0 } \\
\beta \text {-cryptoxanthin-5,8-epoxide ester: C12:0; } \\
\text { 13z/13z-Cryptocapsin ester: C14:0 } \\
\text { Cryptocapsin esters: (C14:0; C16:0; C18:0) }\end{array}$ & Acetone & $\begin{array}{c}\text { YMC C } 30 \\
(250 \times 4.6 \mathrm{~mm} \\
5 \mu \mathrm{m})\end{array}$ & $\begin{array}{c}\text { A: Methanol/MTBE } / \mathrm{H}_{2} \mathrm{O} \\
(81: 17: 2, \mathrm{v} / \mathrm{v} / \mathrm{v}) \\
\text { B: Methanol/MTBE/ } / \mathrm{H}_{2} \mathrm{O} \\
(10: 88: 2, \mathrm{v} / \mathrm{v} / \mathrm{v})\end{array}$ & $\begin{array}{l}\text { HPLC- } \\
\text { DAD- } \\
\text { APCI-MS }\end{array}$ & $\begin{array}{c}\text { Murillo et } \\
\text { al., } 2013\end{array}$ \\
\hline $\begin{array}{c}\text { Papaya } \\
\text { (Carica } \\
\text { papaya L.) }\end{array}$ & $\beta$-cryptoxanthin ester: C10:0; C12:0; C14:0; C16:0 & $\begin{array}{c}\text { Methanol/ } \\
\text { Ethyl } \\
\text { Acetate/ } \\
\text { Petroleum } \\
\text { Ether, } \\
(1 / 1 / 1 ; \\
\mathrm{v} / \mathrm{v} / \mathrm{v}) \\
25^{\circ} \mathrm{C}\end{array}$ & $\begin{array}{c}\text { YMC C30 } \\
(150 \times 3 \mathrm{~mm} \\
3 \mu \mathrm{m})\end{array}$ & $\begin{array}{c}\text { A: Methanol/MTBE } / \mathrm{H}_{2} \mathrm{O} \\
(91: 5: 4, \mathrm{v} / \mathrm{v} / \mathrm{v}) \\
\text { B: Methanol/MTBE/ } \mathrm{H}_{2} \mathrm{O} \\
(6: 90: 4, \mathrm{v} / \mathrm{v} / \mathrm{v})\end{array}$ & $\begin{array}{l}\text { HPLC- } \\
\text { DAD- } \\
\text { APCI }\end{array}$ & $\begin{array}{l}\text { Schweigge } \\
\text { rt et al., } \\
2012\end{array}$ \\
\hline $\begin{array}{l}\text { Mamey } \\
\text { (Pouteria } \\
\text { sapota) }\end{array}$ & Lutein ester: C12:0-C14:0 & $\begin{array}{l}\text { Hexane/ } \\
\text { Dichlorom } \\
\text { etane } \\
(1: 1, \mathrm{v} / \mathrm{v})\end{array}$ & $\begin{array}{l}\text { YMC C30 } \\
(150 \times 4.6 \\
\mathrm{mm})\end{array}$ & $\begin{array}{l}\text { A: Methanol } \\
\text { B: MTBE }\end{array}$ & $\begin{array}{l}\text { HPLC } \\
\text { LC-MS- } \\
\text { TOF }\end{array}$ & $\begin{array}{l}\text { Yahia } e t \\
\text { al., } 2011\end{array}$ \\
\hline Peach & $\beta$-cryptoxanthin esters: $C 12: 0 ; C 14: 0 ; C 16: 0$ & $\begin{array}{c}\mathrm{MeOH}: \mathrm{Et} \\
\mathrm{Ac}: \mathrm{PE} \\
(1: 1: 1 \\
\mathrm{v} / \mathrm{v} / \mathrm{v})\end{array}$ & $\begin{array}{c}\text { YMC C30 } \\
(250 \times 4.6 \mathrm{~mm} \\
-5 \mu \mathrm{m})\end{array}$ & $\begin{array}{c}\text { A: Methanol/MTBE/ } / \mathrm{H}_{2} \mathrm{O} \\
(83: 15: 2, \mathrm{v} / \mathrm{v} / \mathrm{v}) \\
\text { B: Methanol/MTBE/ } \mathrm{H}_{2} \mathrm{O} \\
(8: 90: 2, \mathrm{v} / \mathrm{v} / \mathrm{v})\end{array}$ & $\begin{array}{l}\text { HPLC- } \\
\text { DAD- } \\
\text { APCI-MS }\end{array}$ & $\begin{array}{l}\text { Giuffrida } \\
\text { et al, } 2013\end{array}$ \\
\hline $\begin{array}{l}\text { Tamarillo } \\
\text { fruits } \\
\text { (Solanum } \\
\text { betaceum } \\
\text { Cav.) }\end{array}$ & $\begin{array}{c}\text { All-trans-neoxanthin esters: C14:0-C14:0; C14:0-C16:0; } \\
\text { C16:0-C16:0 } \\
\text { All-trans-5,6-epoxy- } \\
\text { B-cryptoxanthin esters: C14:0; C16:0 } \\
\text { Cis-neoxanthin esters: C14:0-C14:0; C14:0-C16:0 } \\
\text { All-trans-violaxanthin esters: C14:0-C14:0; C14:0-C16:0; } \\
\text { C16:0-C16:0 } \\
\text { All-trans- } \beta \text {-cryptoxanthin esters: C14:0; C16:0 } \\
\text { All-trans-antheraxanthin esters: C14:0-C14:0; C14:0-C16:0; } \\
\text { C16:0-C16:0 } \\
\text { All-trans-lutein esters: C14:0-C14:0; C14:0 C16:0 } \\
\text { All-trans-zeaxanthin: C14:0-C14:0; C14:0-C16:0; C16:0- } \\
\text { C16:0 }\end{array}$ & $\begin{array}{c}\text { Ethanol/H } \\
\text { exane }(4: 3 \\
\text { v/v) }\end{array}$ & $\begin{array}{l}\text { YMC C30 } \\
(250 \times 4.6 \\
\mathrm{mm}, 5 \mu \mathrm{m})\end{array}$ & $\begin{array}{l}\text { A: Water } / 20 \mathrm{mM} \\
\text { ammonium acetate } \\
\text { B: } \mathrm{MeOH} / 20 \mathrm{mM} \\
\text { ammonium acetate } \\
\text { C: MTBE }\end{array}$ & $\begin{array}{l}\text { HPLC/ } \\
\text { PDA-MS }\end{array}$ & $\begin{array}{l}\text { Mertz et } \\
\text { al., } 2010\end{array}$ \\
\hline
\end{tabular}

Structure and properties

Carotenoids are isoprenoidic compounds which can be divided into carotenes (hydrocarbons) and oxygenated derivatives (xanthophylls). The xanthophylls of higher plants posses a C40 backbone which can bear different oxygenated functional groups: hydroxyl, aldehyde, ketone, epoxy, carboxyl. Xanthophylls containing hydroxyl groups, also named carotenol, can be esterified with carboxylic acids, mainly with long chain and saturated ones. The chemical structure of the most common xanthophyll esters is presented in Fig.1.

Most of the physical and chemical properties of carotenoids are due to the presence of the polyenic system. The long system of conjugated double bonds (chromophore) is responsible for the light absorption properties of carotenoids, in consequence also for their colouring properties. Also, the polyene chain is responsible for most of the chemical properties of carotenoids.
Esterification of hydroxyl group does not modify the chromophore, in consequence the UV-VIS light absorption spectra of the esters will be identical with those of the unesterified compounds (Britton, 1995; Britton et al., 2004). However, the molar absorptivity (as well as the specific absorption coefficient $\left.\mathrm{A}^{1 \%}{ }_{1 \mathrm{~cm}}\right)$ is different. The molar absorptivity of xanthophyll ester can be calculated as the product between the specific absorption coefficient $\mathrm{A}^{1 \%}{ }_{\mathrm{lcm}}$ of the unesterified xanthophyll and the ratio between the molecular weight of xanthophyll and the molecular weight of the ester (Schiedt and Liaaen-Jensen, 1995). The similar light absorption properties of esterified and free xanthophylls unable their identification based only on absorption maxima, but it requires proper identification using standards and mass spectra analysis. Mass spectra of xanthophyll diesters are relatively simple and contain six types of ions above $\mathrm{m} / \mathrm{z} 200:[\mathrm{M}]^{+} \cdot-$ the molecular ion (or 
<smiles>[R]C(=O)O[C@@H]1CC(C)=C(/C=C/C(C)=C/C=C/C(C)=C/C=C/C=C(C)/C=C/C=C(C)/C=C/C2=C(C)C[C@H](OC([R])=O)CC2(C)C)C(C)(C)C1</smiles>
Zeaxanthin diester

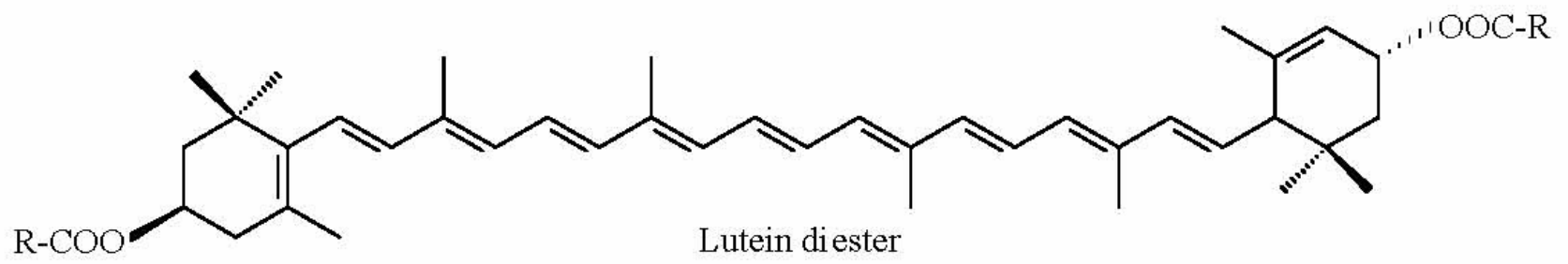<smiles>[R]C(=O)O[C@H]1CC(C)=C(/C=C/C(C)=C/C=C/C(C)=C/C=C/C=C(C)/C=C/C=C(C)/C=C/C2=C(C)CCCC2(C)C)C(C)(C)C1</smiles>

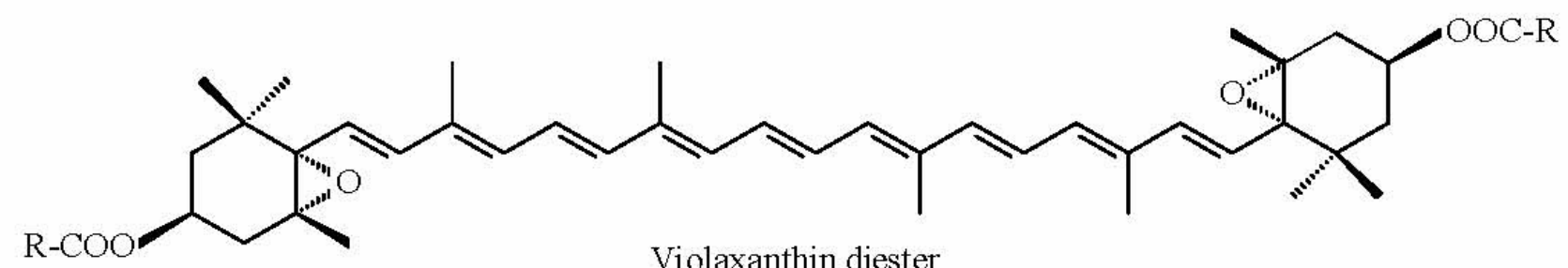

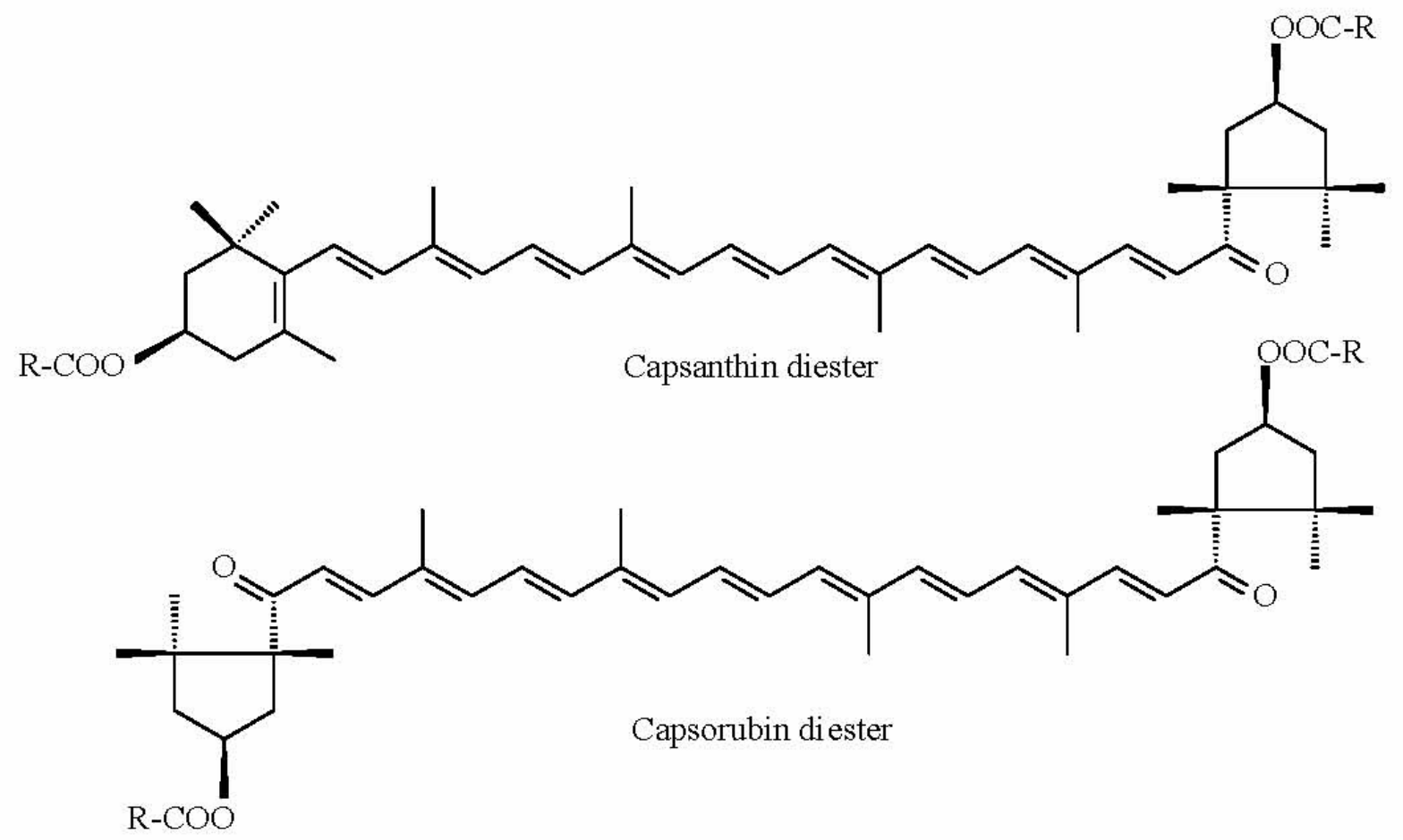

Fig. 1. Structure of major xanthophyll esters in fruits and vegetables 
315

$[\mathrm{M}+\mathrm{H}]^{+}$in APCI positive ionisation mode), [M$\left.\mathrm{R}_{1} \mathrm{COOH}\right]^{+} \cdot, \quad\left[\mathrm{M}-\mathrm{R}_{2} \mathrm{COOH}\right]^{+} \cdot, \quad\left[\mathrm{M}-\mathrm{R}_{1} \mathrm{COOH}-\right.$ $\left.\mathrm{R}_{2} \mathrm{COOH}\right]^{+} \cdot,\left[\mathrm{R}_{1} \mathrm{COOH}\right]^{+} \cdot$ and $\left[\mathrm{R}_{2} \mathrm{COOH}\right]^{+} \cdot$. These fragments correspond to the ester molecule (ionized or protonated), to the consecutive loss of fatty acids moieties and to the fatty acids which esterify the hydroxyl group (Enzell and Back, 1995).

The esterification of xanthophyll decreases the polarity and increases the solubility in lipids. The high molecular weight and the very low polarity confer a special chromatographic behaviour to the xanthophyll esters, which is characterized by higher retention time than carotenes when separated on reversed phase stationary phase (C18 or C30). The chromatographic behaviour of esters depends on the polarity of the parent xanthophyll, on the chain length and unsaturation of the fatty acids. The retention times of carotenol esters on reversed-phase column increases as the number of carbon atoms in the fatty acids moiety increases and decreases with the unsaturation for the same chain length (e.g. linoleic acid esters of lutein elute earlier than stearic acid esters). Also, the esters of violaxanthin (which posseses epoxide group) elute in front of lutein or zeaxanthin esters (Khachik, 2009).

Xanthophyll esters can be hydrolyzed by the common alkaline hydrolysis (methanolic potassium hydroxide or sodium hydroxide) (Schiedt and Liaaen-Jensen, 1995) or by enzymatic hydrolysis with various lipases (as described in the section Metabolism and bioavailability) (Breithaupt et al., 2002; Breithaupt et al., 2007).

Most of the beneficial effects of carotenoids are attributed to their antioxidant activity which was proved by numerous in vitro and in vivo studies. Carotenoids are known as effective quenchers of singlet oxygen, of excited sensitizers and as scavengers of other reactive oxygen species. Antioxidant properties of carotenoids are due to the presence of polyenic system but they can be modified by the presence of different functional groups (Krinsky and Johnson, 2005; Yeum et al., 2009).

The experimental results regarding the antioxidant capacity of xanthophyll esters are contradictory. Lutein, lutein monomyristate and lutein dimyristate were found to have similar antioxidant activities when tested by methyl linoleate hydroperoxide assay and by DPPH (1,1-diphenyl2-picrylhydrazyl) test (Subagio and Morita, 2001). In a later work, the same authors reported that lutein and its dimyristate ester have prooxidant effect on purified triacylglycerols from corn, when heated at $40^{\circ} \mathrm{C}$, in darkness. However, the prooxidant activity of free lutein was more pronounced than that of its dimyristate (Subagio and Morita, 2003). Carotenoid esters of capsanthin and capsorubin from paprika exhibited a better stability toward lipoxygenase catalyzed linoleic acid oxidation than the free xanthophylls (Biacs et al., 1989). The esterified forms of capsanthin were proved to be good radical scavengers, with an antioxidant activity similar to the free form, when assessed by AMVN-induced oxidation of methyl linoleate (Matsufuji et al., 1998). Radical-induced oxidation (with AIPN as initiator) occured at the same rate in the free and the esterified capsanthin and capsorubin, but faster for the zeaxanthin esters than for free zeaxanthin. The differences were explained by the differences in the fatty acids which esterified the xanthophylls. Capsanthin and capsorubin are esterified with saturated fatty acids, while zeaxanthin is esterified mainly with the unsaturated linoleic acid. This proves that beside the xanthophyll, the fatty acid moiety can influence the antioxidant properties of carotenol esters (Pérez-Gálvez and Minguez-Mosquera, 2002, 2005). The scavenging capacity of hydroxyl radical, superoxide anion and singlet oxygen (determined by chemiluminescence) proved that esterification with saturated fatty acids does not affect the antioxidant activity of $\beta$-cryptoxanthin (Fu et al., 2010). Slightly lower antioxidant activity was found for the $\beta$-cryptoxanthin and zeaxanthin esters with unsaturated fatty acids (oleic and linoleic) compared to the saturated esters and to the free forms (Pintea et al., 2013a, 2013b, 2014a).

\section{Extraction and chromatographic separation}

Extraction of xanthophyll esters, as well as of all the carotenoids, requires the use of organic solvents. Several factors are taken into account when choosing the solvents, such as the structure of the matrix containing carotenoid esters and the differences in the polarities of carotenoids found in the matrix. Xanthophyll esters are non-polar compounds and usually, they are extracted with non-polar solvents. However, in different matrices the presence in the matrix of the more polar xanthophylls requires the use of mixtures also containing polar solvents. Acetone, a watermiscible organic solvent dissolves both carotenes and xanthophylls in an efficient way (Rodriquez-Amaya, 2010). Most of the studies regarding carotenoid esters extraction have included acetone as extraction solvent (Delgado-Pelayo and Hornero-Mèndez, 2012; Giuffrida et al., 2013; Murillo et al., 2013). Usually, a mixture of polar and non-polar solvents or acetone alone is used for carotenoid esters extraction from different matrices. A mixture of acetone: hexane $(1: 1, \mathrm{v} / \mathrm{v})$ was used to isolate $\beta$-cryptoxanthin, lutein and antheraxanthin esters from apricots (Prunus armeniaca L.) (Kurz et al., 2008), and for the extraction of 9-cisviolaxanthin and all-trans-violaxanthin esters from mango (Ornelas-Paz et al., 2007). Extraction of carotenoid esters from oranges juices and from sea buckthorn (Hippophae rhamnoides L.) was performed with a mixture of methanol:ethylacetate:petroleum ether (1:1:1, v/v/v) (Giuffrida et al., 2012; Pop et al., 2014; Weller and Breithaupt, 2003). Inbaraj et al. (2008) extracted zeaxanthin and $\beta$-cryptoxanthin esters from Goji (Lycium barbarum) with a mixture of hexane: ethanol:acetone:toluene (10:6:7:7, v/v/v/v). N,N-dimethyl formamide was used for xanthophyll esters extraction from potato (Fernandez-Orozco et al., 2013) and a mixture of 1,2-dichloroethane:acetone:methanol (2:1:1, v/v/v) for carotenoid esters extraction from Capsicum annum L. species (Daood et al., 2014). Almost all the procedures used the addition of $\mathrm{NaHCO}_{3}, \mathrm{MgCO}_{3}$ or $\mathrm{CaCO}_{3}$ in the first steps of the extraction in order to neutralize the acidity of plant tissues and to prevent rearrangements. The extractions are repeated until the residues are colourless and the filtrates are combined, partitioned into a separatory funnel with an adequate solvent (diethyl ether). The organic phase is removed and evaporated and the residue is further dissolved in a suitable amount of solvent for HPLC analysis (Britton, 1995). 
HPLC techniques are widely used for the separation and quantification of carotenoid esters. Unsaponified extracts can be injected directly into HPLC columns or after a previous fractionation by open column chromatography (Bernhard, 1995; Pintea et al., 2005; Subagio et al., 1996). The first attempts to separate carotenoid esters in fruits by HPLC revealed the superiority of reversed phase (octadecylsilane, C18) over the normal phase (silica) column (Philip and Chen, 1988). Khachik and Beecher (1988a, b) developed chromatographic methods for the separation of synthethic diesters with various fatty acids of violaxanthin, auroxanthin, lutein, zeaxanthin, isozeaxanthin, and beta-cryptoxanthin on C18 reversed phase column.

Most of the separation on C18 columns used binary gradients with mobile phases containing various ratio of: acetonitrile/ethyl acetate/water; acetone/water; 2propanol/water/ acetonitrile. Good separation of esters from sarsaparilla berries (Delgado-Pelayo and HorneroMéndez, 2012), potatoes (Fernandez-Orozco et al., 2013) and apples (Delgado-Pelayo et al., 2014) were obtained on C18 RP columns. Sea buckthorn unsaponified extracts containing complex mixtures of carotenes and esters were both separated on C18 column (LiChrosorb RP 18) and on a Waters Acquity UPLC BEH Shield RP18 column (2.1x150 mm, 1,7 x150 mm, $1.7 \mu \mathrm{m}$ ) (Pop et al., 2014). Octadecylsilane C18 column are robust columns which allow good separation of both unesterified and esterified xanthophylls, in a relatively short time, with affordable solvents.

C30 columns of different size are however mostly used for the separation of fatty acid esters of carotenoids in native extracts from fruits or vegetables. Binary or ternary gradients are used, based on a combination in various proportion of the following solvents: methanol/tert-butyl-methylether/water (with or without ammonium acetate) or dichloromethane/methanol/acetonitrile. Good separations on C30 columns of a high number of esters were obtained for apricot (Kurz et al., 2008); Capsicum sp. (Giuffrida et al., 2013); sea buckthorn (Giuffrida et al., 2012; Weller and Breithaupt, 2003); exotic fruits (Murillo et al., 2013). C30 columns provide better separations, especially for long-chain hydrophobic compounds (like xanthophyll esters) and for geometric isomers (Sander et al., 2000). The disadvantages of C30 columns are the longer separation time and more expensive solvents. However, for very complex matrix like sea buckthorn, pepper or citrus fruits, the method of choice is the separation on C30 column with narrow particles ( 3 $\mu \mathrm{m})$.

A particular case is the analysis of carotenoids in mandarin essential oil by LCxLC, where a normal phase column (Supelcosil LC-SI) was used on the first dimension and a reversed phase (Chromolith Performance RP-18) on the second dimension. Beside other carotenoids, eighteen esters of different xanthophylls were identified (Dugo et al., 2008).

Carotenoids are commonly identified based on their light absorption properties using UV-VIS and PDA detectors. Carotenoid esters have the same light absorption properties like the parent compounds and can not be identified solely based on their spectra (position of absorption maxima and the fine structure \%III/II).
The availability of relatively few commercial standards led to the extensive use of hyphenated chromatographic techniques: LC/MS and LC/MALDI. Mass spectrometry detectors provide the molecular peak but also the fragments which can be further used in order to respect the minimum criteria of identification for carotenoids and their esters. Several MS detection methods were reported to use continuous flow fast atom bombardment, matrix-assisted laser desorbtion/ionization (MALDI), electrospray ionization (ESI), atmospheric pressure photoionization (APPI), atmospheric solids analysis probe (ASAP) and atmospheric pressure chemical ionization (APCI). APCI method can form both positively and negatively charged molecular ions species (Amorim-Carrilho et al., 2014; Cacciola et al., 2012; Van Breemen et al., 2012; Wingerath et al., 1997). The LC/APCI-MS method, characterized by high sensitivity and superior linearity of detector response, became the standard analysis method in carotenoid esters analysis. For example, 31 esters were identified in Capsicum sp. (Giuffrida et al., 2013) and 24 esters in apple (DelgadoPelayo et al., 2014). An overview on the extraction, chromatographic methods and detections employed for characterization of unsaponified extracts, as well as the main esters identified in different fruits and vegetables are presented in Tab. 1.

Generally, the quantification of the carotenoids in carried out using the PDA detection and standard curves obtained either with commercially available standards, standards prepared by semi-synthesis (in house) (Weller and Breithaupt, 2003) or with the parent xanthophyll. Due to the difference in absorbtivity, it is recommended that quantitative determination of esters is made by an internal standard calibration with isozeaxanthin esters (e.g. dinonanoate) prepared by acylation (Khachik, 2009). For the analysis of fatty acids profile in ester fraction or in matrices containing carotenoid esters, gas chromatography can be used (Pintea et al., 2005; Pop et al., 2013).

\section{Biosynthesis and accumulation of carotenoid esters}

Carotenoids are tetraterpenes which belong to the large family of isoprenoids. More than 32,000 isoprenoids and about 750 carotenoids have been identified so far. Most of the carotenoids are C40 isoprenoids and they are divided into carotenes (hydrocarbons) and oxygenated derivatives (xanthophylls). Carotenoid pigments are synthesized only by plants and microorganisms, while de novo biosynthesis of carotenoids could not be demonstrated in any animal organism (Britton et al., 1998).

Similarly with other isoprenoids, carotenoids are biosynthesized by the condensation of the $\mathrm{C} 5$ precursors the isopentenyl diphosphate (IPP) and dimethylallyl diphosphate (DMAPP). The biosynthesis of IPP and DMAPP takes place by two routes: the classical acetate mevalonate pathway (MVA) and the lately discovered 2Cmethyl-D-erythritol-4-phosphate (MEP) pathway. The two biosynthetic pathways have different locations - the MVA pathway is localized into the cytosol while the MEP pathway is located in the plastids. In plants carotenoids are biosynthesized from C5 precursors generated mostly by MEP pathway (Moise et al., 2013; Rohmer, 1998). The main steps of carotenoid esters biosynthesis are:

- head-to-tail condensation of C5 units (three IPPs and 
317

one DMAPP) to form the C20 intermediate geranylgeranyldiphosphate (GGPP);

- head-to-head condensation of two GGPP units, catalyzed by phytoene synthase (PSY), to form 15-cisphytoene (a colourless carotenoid);

- desaturation and isomerization reactions to form lycopene;

- cyclization reactions, catalyzed by various cyclases, which leads to the formation of different cyclic carotene structures $(\beta, \varepsilon, \kappa$, etc.);

- chemical changes in the cycle (hydroxylation, epoxidation, etc.) to generate xanthophylls;

- esterification of hydroxyl group with corresponding acyl-coenzyme A (Britton et al., 1998, Giuliano, 2014; Gomez-Garcia and Ochoa-Alejo, 2013; Moise et al., 2013; Shumskaya and Wurtzel, 2013).

Significant progresses in the understanding of carotenoid biosynthesis were made during last years. Most of the enzymes involved in biosynthetic pathway were purified and characterized in several plant models like Arabidopsis, tomato, maize, pepper, daffodil, etc. Recently the gene encoding for the enzyme that catalyzes the xanthophyll esterification (PYP1 - pale yellow petal) was identified in tomato flowers. The PYP 1 protein has two domains, a hydrolase domain and an acyltransferase domain (LPAT - lysophospholipid acyltransferase). It was proved that the deletion or the alteration of the acyltransferase domain abolishes the esterification of xanthophylls and determined the disruption of normal chromoplast development (Ariizumi et al., 2014)

Hydroxyl groups of xanthophylls are often esterified in fruits and flowers with mixtures of fatty acids. Carotenoids are biosynthesized by almost all the plastids, but xanthophyll esterification is associated with the formation of chromoplasts of fruits and flowers and with ripening in fruits (Minguez-Mosquera and Hornero-Méndez, 1994; Ohmiya, 2013). In chloroplasts, carotenoids are localized in the thylakoid membranes as component of the photosynthetic complexes. The major carotenoids in all green leaves are: $\beta$-carotene, lutein, violaxanthin, neoxanthin; while $\alpha$-carotene and zeaxanthin are present in small amounts (Britton, 1995a). Xanthophylls of the chloroplasts are found in non-esterified form and the esterification occurs in senescent leaves, being associated with the degeneration of chloroplasts and the formation of chromoplasts (Biswal, 1995; Cardini, 1982).

Chromoplasts are differentiated from chloroplasts during the ripening of green fruits but also from leucoplasts or amyloplasts during ripening of other fruits or development of roots. Several types of chromoplasts have been described, with different morphologies and containing different types of carotenoid sequestering substructures, such as plastoglobules. It is considered that chromoplasts serve as a metabolic sink for the accumulation of carotenoids ( $\mathrm{Li}$ and Yuan, 2013). Xanthophyll esters were found to be associated with fibrillins and polar lipids to form fibrils in the chromoplasts of red pepper (Deruère et al., 1994). In the isolated chromoplast fibrils of red pepper all the xanthophylls were esterified in proportions varying from 75 to $100 \%$. The authors performed an in vitro study to reconstitute chromoplast fibrils by mixing fibrillin with the lipid components and they found that xanthophyll diesters (zeaxanthin and capsanthin) were the most efficient for fibril assembly. This study demonstrated the critical role of the xanthophyll ester for the fibril formation. Later, Ytterberg et al. (2006) identified twenty-eight proteins in the plastoglobules of red pepper chromoplasts, among them some fibrillins (structural proteins) and an esterase which might be responsible for the esterification of xanthophylls. The esterification process increases significantly the lipofilicity of xanthophylls and has an important physiological relevance for the sequestration of carotenoids in the chromoplasts (Ariizumi et al., 2014; Ohmiya, 2013). It was also proved that the carotenoids stored in plastoglobules have a higher stability to light. Also, their accumulation can contribute to the protection of plastoglobules and light sensitive constituents against blue light (Merzlyak and Solovchenko, 2002).

In red pepper (Capsicum annuum) the xantophylls zeaxanthin, $\beta$-cryptoxanthin, capsanthin and capsorubin are esterified with different fatty acids. Zeaxanthin, capsanthin and capsorubin, which possess two hydroxyl groups, can be present in free form, as monoesters or diesters with different fatty acids, giving rise to a complex carotenoid pattern. Zeaxanthin and $\beta$-cryptoxanthin are esterified mainly with linoleic acid (50-60 \%) while capsanthin and capsorubin are esterified preferentially with middle chain saturated fatty acids. Esterification occurs not only in newly synthesized carotenoids, but also in pigment existing in green fruits, like violaxanthin (Hornero and Mosquera, 2000). Studying five red pepper cultivars, the same authors observed a 23.5 to 48 fold increase of total carotenoids during ripening process, depending on the phenotype. Also, a gradual decrease of the free (F) form of xanthophylls but an increase of partially esterified (PE, monoesters) and totally esterified (TE, diesters) fractions could be observed. Only in the last stage of ripening was a small decrease of TE noticed, as well as an increase of PE, fact that suggests the establishment of a balance between the fractions. Independent on the phenotype, the proportion of the three fractions was similar: $24.17 \pm 4.06(\mathrm{~F}), 31.48 \pm 4.61(\mathrm{PE})$ and $44.36 \pm$ 5.05 (TE).

Similar processes were reported during ripening in apple fruits. Esters of lutein, violaxanthin and neoxanthin with various fatty acids were found in apple peel (Malus pumila, cv. 'Cox's Orange Pippin') (Knee, 1988). The author suggested that esters are synthesized de novo in ripening apples, their concentration increases during ripening independent on ethylene production so they could serve as early indicators of fruit maturity. The changes in the chlorophyll and carotenoid composition in the skin of apple fruits ('Antonovka' variety) in sun and shade ripening, both on and off the tree, were determined. Violaxanthin and neoxanthin, the major esterified xanthophylls in apples, were quantified by HPLC. In shaded apple on the three, xanthophylls esters increased from $1.4 \%$ to $19.7 \%$ (6 September - 11 October) while in sunlit apples there was a dramatical increase, from $5.1 \%$ to $38.4 \%$. In detached fruits, xanthophylls esters reached $50 \%$ in shaded and respectively $95 \%$ in sunlit apples. A decrease of chlorophyll and a significant change in the carotenoid pattern was also observed, with a decrease of $\beta$-carotene and lutein and an increase of carotenoids of xanthophyll cycle (Solovchenko et al., 2006). The changes in carotenoid composition of apple 
skin exposed to sun light could be mediated by the reactive oxygen species generated in these conditions (Merzlyak et al., 2002; Solovchenko et al., 2006).

Mango fruits contain as main compounds $\beta$-carotene and dibutyrates of all-trans-violaxanthin and 9-cisviolaxanthin. The changes in the carotenoid content and the changes in the color in mesocarp and epidermis were determined for two mango cultivars 'Ataulfo' and 'Manila', after harvesting during 16 days. For both cultivars there were significant increases (exponential/second order polynomial) of all carotenoids. All trans-violaxanthin and 9cis-violaxanthin dibutyrates reached $31.97 \times 10^{-3} \mathrm{~g} / \mathrm{kg}$ and $16.81 \times 10^{-3} \mathrm{~g} / \mathrm{kg}$ in the mesocarp of 'Manila' cultivar at the end of experiment. Interestingly, at the moment of harvest/acquisition no 9-cis-violaxanthin esters were detected. The increases in the concentration of all carotenoids were highly correlated with $a^{*}$ and $b^{\circ}$ color values of the mesocarp and epidermis (Ornelas-Paz et al., 2008).

Sea buckthorn berries are known as rich sources of zeaxanthin and $\beta$-cryptoxanthin esters (Pintea et al., 2005; Weller and Breitphaupt, 2003). Depending on the region, the oily berries are normally harvested from August September until late November. A study performed in Sweden on four sea buckthorn cultivars showed a significant increase of total carotenoids during ripening: from $323 \mu \mathrm{g} / \mathrm{g}$ ( $28^{\text {th }}$ of July), to $1015 \mu \mathrm{g} / \mathrm{g}$ ( $15^{\text {th }}$ of September). The most significant increase was recorded for the esterified fraction (from 100 to $648 \mu \mathrm{g} / \mathrm{g}$ ) while free xanthophylls increased only from 61 to $82 \mu \mathrm{g} / \mathrm{g}$ (Andersson et al., 2009). Even thought sea buckthorn oil is characterized by a high content of unsaturated fatty acids, mainly oleic and palmitoleic acid (Pintea et al., 2005), the carotenoid ester fraction is mainly esterified with palmitic and myristic acid. Palmitoleic acid was identified together with palmitic acid in the mixed ester of zeaxanthin, while oleic acid and other unsaturated fatty were found to esterify only lutein and in very small amount sustaining the idea of selective esterification of xanthophylls in plants (Giuffrida et al., 2012). The accumulation of esters during ripening was proved by HPLC-DAD analysis in Physalis alkekengi L. sepals (Bunea et al., 2007).

Interesting data regarding xanthophyll esters accumulation were obtained in the case of red fleshed papaya fruits (Carica papaya L.). Unless in the other fruits, $\beta$-cryptoxanthin esters (caprate and laurate) were already present in early ripening stages of papaya fruits and representing $42 \%$ of total carotenoids. The amount of total carotenoids increased significantly, from $130 \mu \mathrm{g} / 100 \mathrm{~g}$ in ripening stage 1 preharvest to $6214 \mu \mathrm{g} / 100 \mathrm{~g}$ in ripening stage 7 postharvest, as well as the amount of $\beta$ cryptoxanthin (free and esterified). However, the proportion of esters decreased to $19-20 \%$, as well as the ratio $\beta$-cryptoxanthin esters/ $\beta$-cryptoxanthin. Also, the accumulation of esters seems to be dependent on the fatty acids since $\beta$-cryptoxanthin laurate accumulated with much higher rate than other esters (Schweiggert et al., 2011).

Recently Fernandez-Orozco et al. (2014) analyzed sixty potato cultivars and found an average of $23.1 \%$ carotenoids esters. The highest xanthophyll ester content was found at $867.6 \mathrm{lg} / 100 \mathrm{~g}$ dry wt, which represents $58.6 \%$ of total carotenoids. Moreover, the authors found a direct correlation between the total carotenoid content and the ester fraction, suggesting once again the importance of esterification for the sequestration and accumulation of xanthophylls within the plastids. An interesting finding is the high proportion of linoleic acid as esterifying fatty acid (39.0\%), similar with the ester fraction of tritordeum grains were lutein was extensively esterified with linoleic acid (Mellado-Ortega and Hornero-Mendez, 2012). Other fatty acids, like oleic acid ( $14 \%$ of total fatty acids in grains) could not be detected in carotenoid ester fraction. Based on these studies the authors suggest a high specificity of xanthophyll acyl transferase responsible for the formation of xanthophyll esters in plants. On the other hand, it was proved that the fatty acids preferentially esterify the hydroxyl group of the $\beta$ ring in the monoesters fraction of lutein (Khachik et al., 1988b). A preference for esterification of lutein with lauric acid was observed in yellow varieties of raspberry (Carvalho et al., 2013).

\section{Metabolism and bioavailability/bioaccessibility}

Fruits and vegetables are the major sources of dietary carotenoids for human. Due to their lipophilic character, carotenoids are metabolized following the same pathways as dietary lipids. The main steps of carotenoid metabolism are: the release from the food matrix; solubilization and incorporation into micelles; carotenoid uptake by intestinal mucosal cells and absorption (passive and active diffusion); transport in the blood by incorporation into chylomicrons and other lipoproteins; distribution and accumulation in tissues; structural modification and excretion. Bioavailability of carotenoids is affected by several factors, some of the related to the food: the food matrix and the location of carotenoids, the chemical nature of carotenoids (including isomerism), the food processing, the amount of lipid in the food, the interaction between carotenoids and with other components of the food (proteins, fibers). Additionally, the bioavailability/bioaccessibility of carotenoids is affected by human factors, like age, gender, health status (parasitic infections), habits (smokers), etc. All these factors, and probably some others (the existence of "low" or "non-responders"), contribute to a large variability in the carotenoid bioavailability in humans an in the response of human subjects to the supplementation with carotenoids (Canene-Adams and Erdman, 2008; Férnandez-Garcia et al., 2012; Schweigert, 1998).

Xanthophyll esters have to be hydrolyzed before intestinal absorption. In vitro studies have proved that xanthophyll esters (lutein, zeaxanthin and $\beta$-cryptoxanthin) can be hydrolyzed by pancreatic lipase, microbial lipase and by cholesterol esterase (Breithaupt et al., 2002, 2007; Jacobs et al. 1982). In a model of simulated digestion, zeaxanthin esters purified from Lycium chinense were partially hydrolyzed by carboxyl ester lipase (porcine, bovine, colipase or combined) and the hydrolysis increased the efficiency of micellarization. The hydrolysis of esters also increased significantly the uptake of zeaxanthin from micelles by Caco-2 human intestinal cells (Chitchumroonchokchai and Failla, 2006).

In humans, carotenoids esters seem to be efficiently hydrolyzed before absorption. $\beta$-cryptoxanthin concentrations in chylomicrons increased after the ingestion of a tangerine concentrate rich in $\beta$-cryptoxanthin esters, 
319

but no esters were found in blood (Wingerath et al., 1995). Similarly, only small amounts of lutein esters were found in blood (Granado et al., 1998) and in skin (Wingerath et al., 1998) after a long term dietary supplementation with a mixture of lutein esters.

Most of the studies regarding the bioavailability of esters proved that xanthophylls esters have comparable bioavailability with the corresponding free xanthophylls and a comparable increase of plasma free xanthophylls can be observed after supplementation with food or products rich in esters. Lutein diesters were found to be with $61.6 \%$ more bioavailable than unesterified after administration of a single dose (Bowen et al., 2002) but was influenced by the type of formulation (amount of oil), as reported also in a previous study (Roodenberg et al., 2000). Administration of paprika oleoresin ( $1 \mathrm{~g}$ oleoresin with $5 \mathrm{~g}$ oil) containing esterified xanthophyll in healthy volunteers lead to a significant increase of zeaxanthin, $\beta$-cryptoxanthin and $\beta$ carotene in the chylomicrons fraction of plasma. However none of them could be identified in the esterified form, even if in the oleoresin the xanthophylls were mainly present as esters with fatty acids (Pérez-Gálvez et al., 2003). Plasma $\beta$ cryptoxanthin increased significantly after administration of a single dose of both, free or esterified xanthophyll from papaya, supporting their comparable bioavailability and the effective enzymatic cleavage of esters (Breithaupt et al., 2003).

A randomised, single-blind cross over study was performed on volunteers that received equal doses $(5 \mathrm{mg}$ in yoghurt) of zeaxanthin dipalmitate (purified from wolfberry) or unesterified zeaxantin. The plasma samples analyzed by chiral HPLC showed a better bioavailability of esterifed form, even if both forms determined a significant increase of zeaxanthin in plasma (Breithaupt et al., 2004). The bioavailability of zeaxanthin dipalmitate from wolfberry was tested in a human supplementation trial in which the subjects receive $15 \mathrm{~g} /$ day whole fruits (containing about $3 \mathrm{mg}$ zeaxanthin) for 28 days. In the supplementation group the plasma zeaxanthin concentrations increased from 0.038 to $0.096 \mu \mathrm{mols} / \mathrm{l}$, demonstrating that wolfberry is a bioavailable source of carotenoids (Cheng et al., 2005). The significant increase of zeaxanthin in plasma concentration after supplementation with fruits has a particular importance since zeaxanthin bioavailability from spinach or corn is low (Bone et al., 2000; Mozaffarieh et al., 2003). An interesting study on carotenoid bioaccessibility was performed using an in vitro digestion model on carrot, mango, papaya and tomato. The mentioned sources of carotenoids have a different chromoplast morphology which was supposed to influence the release of carotenoids from the food matrix. Xanthophylls and their esters accumulate in liquid-crystalline and lipid dissolved state in globular-tubular substructures of the chromoplasts in the fruits of mango and papaya. Carotenes ( $\beta$-carotene and lycopene) are localized in crystalloid structures in chromoplasts of carrots, tomato and papaya. Generally, the bioaccessibility of all carotenoid was higher for mango and papaya for but xanthophylls ( $\beta$-cryptoxanthin and lutein) and their esters had a superior bioaccessibility then carotenes. The addition of oil improved the bioaccessibility of carotenoids without changing the ranking. It seems that the accumulation of carotenoids (including xanthophylls and their esters) in liquid-crystalline and lipid dissolved state of globular-tubular substructures have a positive effect on their bioaccessibility from fruits and vegetables (Schweiggert et al., 2012).

\section{Stability in model systems and food}

Fruits and vegetables which provide high carotenoid intake are considered very important to maintain health and to reduce the risks of several degenerative diseases or cancer (Krinsky and Johnson, 2005; Rao and Rao, 2007). The carotenoid content in plant derived food is influenced by several factors, such as genetic origin, environmental conditions, cultivation practice and post-harvest treatment. Post-harvest treatment, including transport, storage, processing and cooking, is a key step in preserving the nutritional value of plant food. Carotenoids are more stable in vegetables and fruit than in isolated (purified) form. In plant tissues, carotenoids are protected by molecular interaction with other compounds (proteins, lipids) and by the presence of other antioxidants. Disruption of the tissues exposes carotenoids to light, oxygen and oxidizing enzymes like lipoxygenase (Britton and Khachik, 2009; Caris-Veyrat, 2008; Mercadante, 2008). Xanthophyll esters, as all the carotenoids, are susceptible to degradation under high temperature, light, acidic $\mathrm{pH}$ and reactive oxygen species. The mechanisms involved in carotenoids degradation in food are similar with the degradation of pure compounds and occur mainly through oxidation, geometrical isomerisation, but also by rearrangement of 5,6-epoxides and dehydration. Enzymic oxidation is due to the contact of carotenoids with lipoxygenase which leads to the bleaching of pigments. Non-enzymic oxidation occurs as a consequence of direct interactions of carotenoids with dioxygen molecule or with reactive oxygen species (superoxide anion radical, hydroxyl radical, singlet oxygen and hydrogen peroxide). The non-enzymic oxidation of carotenoids results in the formation of different epoxides and apocarotenals. High temperature, light and low $\mathrm{pH}$ determines the geometrical isomerisation of carotenoids. The position of the double bond of the polyene chain which is isomerized and also the proportion between the $Z$ isomers which are formed depends on the applied treatment (Britton and Khachik, 2009; Caris-Veyrat, 2008; Mercadante, 2008).

The stability of free carotenoids in model systems or in different food systems were reviewed in very comprehensive publications (Maiani et al., 2009; Mercadante, 2008). Compared to free carotenoids, the studies on the stability of xanthophylls esters are relatively scarce and the approaches used are very different. Thermal stability of xanthophyll esters was evaluated using purified esters or on food containing esters. Using purified lutein mono- and dimyristate Subagio et al. (1999) found that they were more stable toward heat treatment and UV light than free lutein, suggesting that esterification with saturated fatty acid stabilize the highly unsaturated lutein. More recently, the thermal stability of $\beta$-cryptoxanthin esters with saturated fatty acids compared to free $\beta$-cryptoxanthin was determined in tetrahydrofuran solutions during incubation at $50{ }^{\circ} \mathrm{C}$, in dark, for up to 72 hours. The stability of pigments, determined by HPLC-PDA, showed that $\beta$ cryptoxanthin esters were more stable than free $\beta$ - 
cryptoxanthin (Fu et al., 2010). Thermal stability tests were performed at different temperatures on $\beta$-cryptoxanthin and zeaxanthin esterified with saturated (myristic and palmitic acids) and unsaturated fatty acids (oleic and linoleic acids) compared with the free xanthophylls. At all temperatures, the esters with saturated fatty acids showed a significantly better stability than the free xanthophylls, while the esters with unsaturated fatty acids exhibited lower stability than the saturated ones, but still higher than the free $\beta$-cryptoxanthin and zeaxanthin (Bunea et al., 2013; Pintea et al., 2013). Lutein esters (mono- and dimyristate were found to be more stable toward UV light than free lutein (Subagio et al., (1999). Contrarily, the photostability toward UVA irradiation was found to be lower for $\beta$ cryptoxanthin palmitate then for free cryptoxanthin, both in hexane solution and in liposomes containing carotenoids. The degradation rate was higher for carotenoids in liposomes and the highest degradation rate was recorded for $\beta$-cryptoxanthin palmitate (Arita et al., 2004).

Relatively few papers were published on the stability of xanthophyll esters in fruits or vegetables. Khachik and Beecher (1988a, b) found that xanthophylls esters in squash were more stable than free carotenoids. Diesters of violaxanthin were more stable than monoesters during cooking and no significant izomerization nor epoxide rearrangement were observed. Stability studies were performed on red peppers (Capsicum annuum L.) and hot chilli peppers (Capsicum frutescens $\mathrm{L}$.) pods minced, heated for $5 \mathrm{~min}$ at 80,90 or $100{ }^{\circ} \mathrm{C}$ and then lyophilised. Caspsanthin, capsorubin, zeaxanthin and $\beta$-cryptoxanthin mono- and diesters from both types of peppers showed comparable photo- and thermal stability, in all the cases higher than for non-esterified forms (Schweiggert et al, 2007).

A different approach was applied for investigation of thermal lability of carotenoids of tamarillo fruits (Solanum betaceum Cav). In this study, the samples were heated (at $80,90,95^{\circ} \mathrm{C}$ ) in hermetically sealed amber vials, in both degassed and not degassed nectar, in which the final level of oxygen was determined. HPLC-PDA/MS analysis of samples before and after treatment showed that zeaxanthin esters appeared to be the less thermo-labile carotenoids, in both experimental conditions (Mertz et al., 2010).

Most of the stability studies performed on pure esters (isolated or synthesized), in esters fractions or in plant materials rich in xanthophyll esters demonstrated the protective effect of esterification, especially with saturated fatty acids.

\section{Conclusions}

Xanthophyll esters represent an important fraction of total carotenoids in many fruits and vegetables. The major xanthophylls present in esterified form are lutein, zeaxanthin, $\beta$-cryptoxanthin, violaxanthin, capsanthin and capsorubin. Commonly consumed fruits and vegetables, like apples, apricots, mandarins, mangoes, papayas, red and chilli peppers, potatoes or squash, contain xanthophylls mainly in esterified form. Some other rich sources have been identified, like: wolfberry (goji), sea buckthorn, persimmon and exotic fruits (sapote, maracuja, frutita, mamey, sastra, corozo, tamarillo, etc).
Identification of carotenoid esters in very complex unsaponified extracts requires powerful chromatographic techniques and mass spectrometry detectors. Significant progresses were reported during last years due to the technical development of separation and identification tools. Also, there is an increasing interest in the characterization of unsaponified extracts which, in contrast to the saponified ones, reflects the native composition of food. Lutein esters have been identified as major compounds in squash; zeaxanthin esters are present in wolfberry, sea buckthorn and red pepper; $\beta$-cryptoxanthin esters in apricots, sea buckthorn, mandarin; violaxanthin and neoxanthin esters in apple and capsanthin and capsorubin esters in pepper.

Esterification of xanthophylls has physiological significance for the chromoplast formation. The increased lipophilicity of esters is important for the sequestration of carotenoids and for the formation of specialized structures (plastoglobules, fibrils) in the chromoplasts. The esters also provide protection against photooxidative damages in plants. Esterification process and accumulation of esters occurs during ripening in fruits and is associated with significant change in the colour of fruits. Even if the specific enzymes which catalyze the esterification process were not characterized yet, detailed analytical data regarding the carotenoid composition suggests a selectivity of these enzymes for certain fatty acids and selectivity for the ring in the case of non-symmetric carotenoids like lutein.

Xanthophyll esters seem to be efficiently hydrolyzed and absorbed in humans leading to a comparable bioavailability to the unesterified compounds. Also, the xanthophyll esters preserve the antioxidant capacity of the parent compounds while having a better stability in fruits during storage and processing. All these properties are important from the perspective of the use of fruits rich in xanthophyll esters as valuable components of the human diet and as sources of bioactive compounds in the prevention of severe degenerative diseases.

\section{Acknowledgements}

This work was supported by the grants of the Romanian National Authority for Scientific Research CNCSUEFISCDI, project number PN-II-ID-PCE-2011-3-0721.

\section{References}

Amorim-Carrilho KT, Cepeda A, Fente C, Regal P (2014). Review of methods for analysis of carotenoids. TRAC-Trend Anal Chem 56:49-73.

Andersson S, Olsson ME, Johansson E, Rumpunen K (2009). Carotenoids in sea buckthorn (Hippophae rhamnoides L.) berries during ripening and use of Pheophytin a as a maturity marker. J Agric Food Chem 57:250-258.

Ariizumi T, Kishimoto S, Kakami R, Maoka T, Hirakawa H, Suzuki Y, Ozeki Y, Shirasawa K, Bernillon S, Okabe Y, Moing A, Asamizu E, Rothan C, Ohmiya A, Ezura H (2014. Identification of the carotenoid modifying gene Pale Yellow Petal 1 as an essential factor in xanthophyll esterification and yellow flower pigmentation in tomato (Solanum lycopersicum). Plant J 79:453-465. 
321

Arita S, Otsuki K, Osaki K, Murata Y, Shimoishi Y, Tada M (2004). Reduction in photostability by esterification of $\beta$ cryptoxanthin. Biosci Biotechnol Biochem 68(2):451-453.

Bernhard K (1995). Chromatography: Part II Column Chromatography, p. 81-108. In: Carotenoid. Vol. 1A: Isolation and Analysis, Britton G, Liaaen-Jensen S, Pfander H (Eds.). Birkhauser Verag, Basel.

Bernstein PS, Khachik F, Carvalho LS, Muir GJ, Zhao DY, Katz NB (2001). Identification and quantitation of carotenoids and their metabolites in the tissues of the human eye. Exp Eye Res 72(3):215-223.

Biacs PA, Daood HG, Pavisa A, Hajdu F (1989). Studies on the carotenoid pigments of paprika (Capsicum annuum $\mathrm{L}$. var $\mathrm{Sz}$ 20). J Agric Food Chem 37:350-353.

Biswal B (1995). Carotenoid catabolism during leaf senescence and its control by light. J Photoch Photobio B 30(1):3-13.

Bone RA, Landrum JT, Dixon Z, Chen Y, Llerena CM (2000). Lutein and zeaxanthin in the eyes, serum and diet of human subjects. Exp Eye Res 71:239-245.

Bowen PE, Herbst-Espinosa SM, Hussain EA, StacewiczSapuntzakis M (2002). Esterification does not impair lutein bioavailability in humans. J Nutr, 132(12):3668-3673.

Breithaupt DE, Bamedi A (2001). Carotenoid Esters in Vegetables and Fruits: A Screening with Emphasis on $\beta$ Cryptoxanthin Esters. J Agr Food Chem 49: 2064-2070.

Breithaupt DE, Bamedi A (2002a). Carotenoids and carotenoid esters in potatoes (Solanum tuberosum L.): new insights into an ancient vegetable. J Agric Food Chem 50:7175-7181.

Breithaupt DE, Bamedi A, Wirt U (2002). Carotenol fatty acid esters: easy substrates for digestive enzymes. Comp Biochem Physiol B 132:721-28.

Breithaupt DE, Weller P, Wolters M, Hahn A (2003). Plasma response to a single dose of dietary $\beta$-cryptoxanthin esters from papaya (Carica papaya L.) or non-esterified $\beta$ cryptoxanthin in adult human subjects: a comparative study. Br J Nutr 90:795-801.

Breithaupt DE, Weller P, Wolters M, Hahn A (2004). Comparison of plasma responses in human subjects after the ingestion of 3R, 3R9-zeaxanthin dipalmitate from wolfberry (Lycium barbarum) and non-esterified 3R, 3R9-zeaxanthin using chiral high-performance liquid chromatography. Br J Nutr 91:707-713.

Breithaupt DE, Alpman A, Carrière F (2007). Xanthophyll esters are hydrolyzed in the presence of recombinant human pancreatic lipase. Food Chem 103:651-656.

Britton G (1995a). Worked examples of isolation and analysis. Example 1: Higher plants. In Carotenoid, Vol. 1A: Isolation and Analysis, Britton G, Liaaen-Jensen S, Pfander H (Eds.). Birkhauser Verlag, Basel, p. 201-214.

Britton G (1995b). UV-Visible Spectroscopy. In: Carotenoid, Vol. 1B: Spectroscopy, Britton G, Liaaen-Jensen S, Pfander H (Eds.). Birkhauser Verlag, Basel, p. 13-62.

Britton G (1998). Overview of carotenoids biosynthesis, p. 13140. In: Carotenoids. Vol. 3: Biosynthesis and Metabolism,
Britton G, Liaaen-Jensen S, Pfander H (Eds.). Birkhauser Verlag, Basel.

Britton G, Liaaen-Jensen S, Pfander H (2004). Carotenoids Handbook. Birkhauser Verlag: Basel, Switzerland.

Britton G, Khachik F (2009). Carotenoids in food. In Carotenoids. Vol. 5 Nutrition and Health, Britton G, LiaaenJensen S, Pfander H (Eds.). Birkhauser Verlag, Basel, p. 45-66.

Bunea A, Andrei S, Rugina D, Pintea A (2013). Thermal and light stability of $\beta$-cryptoxanthin esters. Proceedings of the $7^{\text {th }}$ International Congress on Pigments in Food. Novara, Italy, 170-173.

Bunea A, Pintea A, Socaciu C (2007). HPLC separation of carotenoids from Physalis alkekengi L. in different stages of maturation. Annals of West University of Timişoara, Series of Chemistry 16(2):129-134.

Burmeister A, Bondiek S, Jerz G, Fleischmann P (2013). Carotenoid ester profiles in Solanum tuberosum and Solanum phureja cultivars. Proceedings of the $7^{\text {th }}$ International Congress on Pigments in Food. Novara, Italy, 26-29.

Cacciola F, Donato P, Beccaria M, Dugo P, Mondello L (2012). Advanced in LC-MS for Food Analysis. LC GC Eur. 15-24 (special issue).

Canene-Adams K, Erdman JW (2009). Absorption, Transport, Distribution in Tissues and Bioavailability, p. 115-148. In Carotenoids, Vol. 5 Nutrition and Health, Britton G, LiaaenJensen S, Pfander H (Eds.). Birkhauser Verlag, Basel.

Cardini F (1982). Carotenoids in ripe green and in autumn senescing leaves of apple tree: I - Qualitative composition of free carotenoids, xanthophyll esters and fatty acids of esters. Giornale Botanico Italiano 116:97-115.

Caris-Veyrat C (2008). Antioxidant and prooxidant actions and stabilities of carotenoids in vitro and in vivo and carotenoids oxidation products, p. 177-192. In Food Colorants: Chemical and Functional properties. Socaciu C (Ed.). CRC Press, Taylor \& Francis Group, Boca Raton, London, New York.

Carvalho E, Fraser PD, Martens S (2013). Carotenoids and tocopherols in yellow and red raspberries. Food Chem 139:744-752.

Cheng CY, Chung WY, Szeto YT, Benzie IFF (2005). Fasting plasma zeaxanthin response to Fructus barbarum L. (wolfberry; Kei Tze) in a food-based human supplementation trial. Br J Nutr 93:123-130.

Chew EY, Bressler S, Fish G, Hubbard B, Klein M, Chandra S, Blodi B, Domalpally A, Friberg T, Wong W, Rosenfeld P, Clemons TE, Agron E, Toth C, Bernstein P, Sperduto R, SanGiovanni JP, Danis R, Ferris FL, Elman M, Antoszyk A, Ruby A, Orth D (2013). Lutein plus zeaxanthin and omega-3 fatty acids for age-related macular degeneration the age-related eye disease study 2 (AREDS2) Randomized Clinical Trial. JAMA-J Am Med Assoc 309:2005-2015.

Chitchumroonchokchai C, Failla ML (2006). Hydrolysis of Zeaxanthin Esters by Carboxyl Ester Lipase during Digestion Facilitates Micellarization and Uptake of the Xanthophyll by Caco-2 Human Intestinal Cells. J Nutr 136:588-594. 
Daood HG, Palotás G, Palotás G, Somogyi G, Pék Z, Helyes L (2014). Carotenoid and antioxidant content of ground paprika from indoor-cultivated traditional varieties and new hybrids of spice red peppers. Food Res Int DOI: 10.1016/j.foodres.2014.04.048

Delgado-Pelayo R, Hornero-Méndez D (2012). Identification and quantitative analysis of carotenoids and their esters from sarsaparilla (Smilax aspera L.) Berries. J Agr Food Chem 60:8225-8232.

Delgado-Pelayo R, Gallardo-Guerrero L, Hornero-Méndez D (2014). Carotenoid pigments in peel and flesh of commercial apple fruit varieties. Food Res Int http://dx.doi.org/10.1016/j.foodres.2014.03.025

Deruère J, Römer S, d'Harlingue A, Backhaus RA, Kuntz M, Camara B (1994). Fibril assembly and carotenoid overaccumulation in chromoplasts: a model for supramolecular lipoprotein structures. Plant Cell 6:119-133.

Dufossé L (2009). Microbial and Microalgal Carotenoids as Colourants and Supplements. In Carotenoids, p. 83-98. Vol. 5 Nutrition and Health, Britton G, Liaaen-Jensen S, Pfander H (Eds.). Birkhauser Verlag, Basel.

Dugo P, Herrero M, Kumm T, Giuffrida D, Dugo G, Mondello L (2008). Comprehensive normal-phase $\mathrm{x}$ reversed-phase liquid chromatography coupled to photodiode array and mass spectrometry detection for the analysis of free carotenoids and carotenoid esters from mandarin. J Chromatogr A 1189:196206.

Enzell CR, Back S G (1995). Mass Spectrometry, p. 261-320. In: Carotenoid, Vol. 1B: Spectroscopy, Britton G, Liaaen-Jensen S, Pfander H (Eds.), Birkhauser. Verlag, Basel.

Férnandez-Garcia E, Carvajal-Lérida I, Jarén-Galan M, GarridoFernandez J, Pérez-Galvez A, Hornero-Méndez D (2012). Carotenoids bioavailability from foods: From plant pigments to efficient biological activities. Food Res Int 46:438-450.

Fernandez-Orozco R, Gallardo-Guerrero L, Hornero-Méndez D (2013). Carotenoid profiling in tubers of different potato (Solanum sp) cultivars: Accumulation of carotenoids mediated by xanthophyll esterification, Food Chem 141:2864-2872.

Fu HF, Xie B, Gan F, Ma S, Zhu XR, Pan SY (2010). Effect of esterification with fatty acid of $\beta$-cryptoxanthin on its thermal stability and antioxidant activity by chemiluminescence method. Food Chem 122:602-609.

Giuffrida D, La Torre L, Stelitano M, Pellicanò TM, Dugo G (2006). Application of HPLC-APCI-MS a C-30 reversed phase column for the characterization of carotenoid esters in mandarin essential oil. Flavour Fragr J 21:319-323.

Giuffrida D, Dugo P, Salvo A, Saitta M, Dugo G (2010), Free carotenoid and carotenoid ester composition in native orange juices of different varieties. Fruits 65:277-284.

Giuffrida D, Pintea A, Dugo P, Torre G, Pop RM, Mondello L (2012). Determination of carotenoids and their esters in fruits of seabuckthorn (Hippopae rhamnoides L.) by HPLC-DADAPCI-MS. Phytochem Anal 23(3):267-273.
Giuffrida D, Dugo P, Torre G, Bignardi C, Cavazza A, Corradini C, Dugo G (2013). Characterization of 12 Capsicum varieties by evaluation of their carotenoid profile and pungency determination. Food Chem 140:794-802.

Giuffrida D, Torre G, Dugo P, Dugo G (2013). Determination of the carotenoid profile in peach fruits, juice and jam. Fruits 68:39-44.

Giuliano G (2014). Plant carotenoids: genomics meets multi-gene engineering. Curr Opin Plant Biol 19:111-117.

Gomez-Garcia MR, Ochoa-Alejo N (2013). Biochemistry and molecular biology of carotenoid biosynthesis in chili peppers (Capsicum spp.). Int J Mol Sci 14:19025-19053.

Goodwin TW. 1980. Carotenoids in higher plants. In: The Biochemistry of the Carotenoids, Vol. I. Chapman and Hall: New York.

Granado F, Olmedilla B, Gil-Martinez E, Blanco I (1988). Lutein ester in serum after lutein supplementation in human subjects,. Br J Nutr 80:445-449.

Gregory GK, Chen TS, Philip T (1986). Quantitative analysis of lutein esters in marigold flowers (Tagetes erecta) by high performance liquid chromatography. J Food Sci 51:10931094.

Hornero-Mendez D, Gomez-Landron De Guerva R, MínguezMosquera MI (2000). Carotenoid biosynthesis changes in five red pepper (Capsicum annuum L.) cultivars during ripening. Cultivar selection for breeding. J Agric Food Chem 48:38573864.

Inbaraj BS, Lu H, Hung CF, Wu WB, Lin CL, Chen BH (2008). Determination of carotenoids and their esters in fruits of Lycium barbarum Linnaeus by HPLC-DAD-APCI-MS. Journal Pharmaceut Biomed 47:812-818.

Jacobs PB, LeDoeuft RD, McCommast SA, Tauber JD (1982). The cleavage of carotenoid esters by cholesterol esterase. Comp Biochem Physiol 72B:157-160.

Khachik F, Beecher GR (1988a). Separation and identification of carotenoids and carotenol fatty acids esters in some squash products by liquid chromatography. 1. Quantification of carotenoids and related esters by HPLC. J Agric Food Chem 36:929-937.

Khachik F, Beecher GR, Lusby WR (1988b). Separation and identification of carotenoids and carotenol fatty acid esters in some squash products by liquid chromatography. 2. Isolation and characterization of carotenoids and related esters. J Agric Food Chem, 36:938-946.

Khachik F. (2009). Analysis of carotenoids in nutritional studies, p. 7-44. In: Carotenoids, Vol. 5 Nutrition and Health, Britton G, Liaaen-Jensen S, Pfander H (Eds.). Birkhauser Verlag, Basel.

Knee M (1988). Carotenol esters in developing apple fruits. Phytochem 27(4):1005-1009.

Krinsky NI, Johnson EJ (2005). Carotenoid actions and their relation to health and disease. Molec Aspect Med 26:459-516.

Kurz C, Carle R, Schieber A (2008). HPLC-DAD-MS 
323

characterization of carotenoids from apricots and pumpkins for the evaluation of fruit product authenticity. Food Chem 110: 522-530.

Landrum JT, Bone RA, Joa H, Kilburn MD, Moore LL, Sprague KE (1997). A one year study of the macular pigment: the effect of 140 days of a lutein supplement. Exp Eye Res 63:5762.

Li L, Yuan H (2013). Chromoplast biogenesis and carotenoid accumulation. Arch Biochem Biophys 539:102-109.

Maiani G, Caston MJP, Catasta G, Toti E, Cambrodon IG, Bysted A, Granado-Lorencio F, Olmedilla-Alonso B, Knuthsen P, Valoti M, Böhm V, Miebach EM, Behsnillan, Schlemmer U (2009). Carotenoids: Actual knowledge on food sources, intakes, stability and bioavailability and their protective role in humans, Mol Nutr Food Res 53:S194-S218.

Matsufuji H, Nakamura H, Chino M, Tkeda M (1998). Antioxidant activity of capsanthin and the fatty acid esters in paprika (Capsicum annuum). J Agric Food Chem 46:34683472.

Mellado-Ortega E, Hornero-Méndez D (2012). Isolation and identification of lutein esters, including their regioisomers, in tritordeum (Tritordeum Ascherson et Graebner) grains: Evidence for a preferential xanthophyll acyltransferase activity. Food Chem 135:1344-1352.

Mercadante AZ (2008). Carotenoids in Foods: Sources and stability during processing, p. 241-276. In: Food Colorants: Chemical and Functional properties, Socaciu C (Ed.). CRC Press, Taylor \& Francis Group, Boca Raton, London, New York.

Mertz C, Brat P, Caris-Veyrat C, Gunata Z (2010). Characterization and thermal lability of carotenoids and vitamin C of tamarillo fruit (Solanum betaceum Cav.). Food Chem 119:653-659.

Merzlyak MN, Solovchenko AE (2002). Photostability of pigments in ripening apple fruit: a possible photoprotective role of carotenoids during plant senescence. Plant Sci 163:881888.

Mínguez-Mosquera MI, Hornero-Méndez D (1994). Changes in carotenoid esterification during the fruit ripening of Capsicum annuum cv. Bola. J Agric Food Chem 42:640-644.

Moise AR, Al-Babili S, Wurtzel ET (2014). Mechanistic aspects of carotenoid biosynthesis. Chemical Reviews 114:164-193.

Mozaffarieh M, Sacu S, Wedrich A (2003). The role of the carotenoids, lutein and zeaxanthin, in protecting against agerelated macular degeneration: a review based on controversial evidence. Nutr J 2:20-31.

Murillo E, Giuffrida D, Menchaca D, Dugo P, Torre G, Meléndez-Martinez AJ, Mondello L (2013). Native carotenoids composition of some tropical fruits. Food Chem 140:825-836.

Ohmiya A (2013). Qualitative and quantitative control of carotenoid accumulation in flower petals. Sci HorticAmsterdam 163:10-19.
Ornelas-Paz JI, Yahia ME, Gardea-Bejar A (2007). Identification and quantification of xanthophyll esters, carotenes, and tocopherols in the fruit of seven mexican mango cultivars by Liquid Chromatography-Atmospheric Pressure Chemical Ionization-Time-of-Flight Mass Spectrometry (LC-(APcI+)MS). J Agric Food Chem 55:6628-6635.

Ornelas-Paz JJ, Yahia EA, Gardea AA (2008). Changes in external and internal color during postharvest ripening of 'Manila' and 'Ataulfo' mango fruit and relationship with carotenoid content determined by liquid chromatography-APcI+-timeof-flight mass spectrometry. Postharvest Biol Tec 50:145-152.

Pattison DJ, Symmons DPM, Lunt M, Welch A, Bingham SA, Day NE, Silman AJ (2005). Dietary $\beta$-cryptoxanthin and inflammatory polyarthritis: results from a population-based prospective study. Am J Clin Nutr 82:451-455.

Perez-Gálvez A, Minguez-Mosquera MI (2002). Degradation of non-esterified and esterified xanthopylls by free radicals. Biochim Biophys Acta 1569:31-34.

Pérez-Gálvez A, Martin HD, Sies H, Stahl W (2003). Incorporation of carotenoids from paprika oleoresin into human chylomicrons. Br J Nutr 89:787-793.

Pérez-Gálvez A, Minguez-Mosquerra MI (2005). Esterification of xanthophylls and its effect on chemical behavior and bioavailability of carotenoids in the human. Nutr Res 25:631640.

Philip T, Chen TS (1988). Separation and quantitative analysis of some carotenoid fatty esters of fruits by liquid chromatography. J Chromatogr 435(1):113-136.

Pintea A, Varga A, Stepnowski P, Socaciu C, Culea M, Diehl HA (2005). Chromatographic analysis (HPLC, GC) of carotenol fatty acids esters in Physalis alkekengi and Hippophae rhamnoides, Phytochem Anal 16:188-195.

Pintea A, Bunea A, Socaciu C. (2013a). Effect of esterification on thermal stability and antioxidant activity of zeaxanthin. Proceedings of the 7 th International Congress on Pigments in Food. Novara, Italy, 174-177.

Pintea A, Rugină D, Bunea A, Andrei S (2013b). Impact of esterification on the antioxidant Capacity of $\beta$-cryptoxanthin. Bulletin USAMV Series Animal Science and Biotechnology 70(1):79-85.

Pintea A, Bunea A, Socaci S, Socaciu C (2014). Effect of esterification on the antioxidant activity of zeaxanthin. Carotenoid Science Proceedings Abstract 17th international symposium on carotenoids 10:142.

Pintea A (2008). Food Colorants derived from Natural Sources by Processing. In: Food Colorants - chemical and functional properties (ed. Socaciu C). CRC Press, Taylor and Francis, p. 329-347.

Pinto de Abreu F, Dornier M, Dionisio AP, Carail M, CarisVeyrat C, Dhuique-Mayer C (2013). Cashew apple (Anacardium occidentale L.) extract from by-product of juice processing: A focus on carotenoids. Food Chem 138:25-31.

Pop RM, Weesepoel Y, Socaciu C, Pintea A. Vincken JP, 
Gruppen H (2014). Carotenoid composition of berries and leaves from six Romanian seabuckthorn (Hippophae rhamnoides L.) varieties. Food Chem 147:1-9.

Rao AV, Rao RG (2007). Carotenoids and human health. Pharm Res 55:207-216.

Rodriguez-Amaya DB (2010). Quantitative analysis, in vitro assessement of bioavailability and antioxidant activity of food carotenoids - A review. J Food Comp Anal 23:726-740.

Rohmer M (1999). The discovery of a mevalonate-independent pathway for isoprenoid biosynthesis in bacteria, algae and higher plants. Nat Prod Rep 16:565-574.

Roodenberg AJC, Leenen R. van het Hof KH, Weststrate JA, Tijburg LBM (2000). Amount of fat in the diet affects the bioavailability of lutein esters but not of $\alpha$-carotene, $\beta$ carotene, and vitamin E in humans. Am J Clin Nutr 71:11871193.

Sander LC, Sharpless KE, Pursch M. (2000). C30 stationary phases for the analysis of food by liquid chromatography. J Chromatog A 880:189-202.

Schalch W, Landrum JT, Bone RA (2009). The Eye, p. 301-334. In: Carotenoids, Vol. 5 Nutrition and Health, Britton G, Liaaen-Jensen S, Pfander H (Eds.). Birkhauser Verlag, Basel.

Schiedt K, Liaaen-Jensen S (1995). Isolation and Analysis, p. 81108. In Carotenoid, Vol. 1A: Isolation and Analysis, Britton G, Liaaen-Jensen S, Pfander H (Eds.). Birkhauser Verlag, Basel.

Schumskaya M, Wurtzel ET (2013). The carotenoid biosynthetic pathway: Thinking in all dimensions. Plant Science 208:5863.

Schweigert FJ (1998). Metabolism of Carotenoids in Mammals, p. 249-284. In: Carotenoids, Vol. 3 Biosynthesis and Metabolism, Britton G, Liaaen-Jensen S, Pfander H (Eds.). Birkhauser Verlag, Basel.

Schweiggert RM, Steingass CB, Mora E, Esquivel P, Carle R (2011). Carotenogenesis and physico-chemical characteristics during maturation of red fleshed papaya fruit (Carica papaya L.). Food Res Int 44:1373-1380.

Schweiggert RM, Mezger D, Schimpf F, Steingass CB, Carle R (2012). Influence of chromoplast morphology on carotenoid bioaccessibility of carrot, mango, papaya, and tomato. Food Chem 135:2736-2742.

Schweiggert RM, Steingass CB, Esquivel P, Reinhold C (2012). Chemical and morphological characterization of Costa Rican papaya (Carica papaya L.) Hybrids and lines with particular focus on their genuine carotenoid profiles. J Agric Food Chem 60:2577-2585.

Schweiggert U, Kurz C, Schieber A, Carle R (2007). Effects of processing and storage on the stability of free and esterified carotenoids of red peppers (Capsicum anuum L.) and hot chilli peppers (Capsicum frutescens L.). Eur Food Res Technol 225:261-270.
Solovchenko AE, Avertcheva OV, Merzlyak MN (2006). Elevated sunlight promotes ripening-associated pigment changes in apple fruit. Postharvest Biol Tec 40:183-189.

Subagio A, Morita N (2001). No effect of esterification with fatty acid on antioxidant activity of lutein. Food Res Int 34:315320.

Subagio A, Morita N (2003). Prooxidant activity of lutein and its dimyristate esters in corn triacylglyceride. Food Chem 81:97102.

Subagio A, Wakaki H, Morita N (1999). Stability of lutein and its myristate esters, Biosci Biotechnol Biochem 63(10):17841786.

Van Breemen RB, Dong L, Pajkovic ND (2012). Atmospheric pressure chemical ionization tandem mass spectrometry of carotenoids. Int J Mass Spectrom 312:163-172.

Weller P, Breithaupt DE (2003). Identification and quantification of zeaxanthin esters in plants using liquid chromatographymass spectrometry. J Agric Food Chem 51:7044-7049.

Wingerath T, Sies H, Stahl W (1998). Xanthophyll esters in human skin. Arch Biochem Biophys 355:271-274.

Wingerath T, Stahl W, Kirsch D, Kaufmann R, Sies H (1997). Fruit Juice Carotenol Fatty Acid Esters and Carotenoids As Identified by Matrix-Assisted Laser Desorption Ionization (MALDI) Mass Spectrometry. J Agric Food Chem 44:20062013.

Wingerath T, Stahl W, Sies H (1995). $\beta$-Cryptoxanthin selectively increased in human chylomicrons upon ingestion of tangerine concentrate rich $\beta$-cryptoxanthin esters. Arch Biochem Biophys. 324:385-390.

Wu C, Han L, Riaz H, Wang S, Cai K, Yang L (2013). The chemopreventive effect of $\beta$-cryptoxanthin from mandarin on human stomach cells (BGC-823). Food Chem 136:11221129.

Yahia EM, Gutierrez-Orozco F, Arvizu-de Leon C (2011). Pytochemical and antioxidant characterization of mamey (Pouteria sapota Jacq. H.E. Moore \& Stearn) fruit. Food Res Int 44:2175-2181.

Yamaguchi M. (2012). Role of carotenoid $\beta$-cryptoxanthin in bone homeostasis. J Biomed Sci 19:36.

Yeum KJ, Aldini G, Russel RM, Krinsky NI (2009). Antioxidant/Pro-oxidant actions of carotenoids, p. 235-268. In: Carotenoids, Vol. 5 Nutrition and Health, Britton G, Liaaen-Jensen S, Pfander H (Eds.). Birkhauser Verlag, Basel.

Ytterberg AJ, Peltier J, Van Wijk KJ (2006). Protein profiling of plastoglobules in chloroplasts and chromoplasts: a surprising site for differential accumulation of metabolic enzymes. Plant Physiol 140:984-997.

Zhao L-Q, Qiu Z-Q, Narasimhamoorthy B, Greaves JA (2013). Development of a rapid, high-throughput method for quantification of zeaxanthin in Chinese wolfberry using HPLC-DAD. Ind Crop Prod 47:51-57. 